\title{
Protoceratium reticulatum (Dinophyceae) in the austral Southwestern Atlantic and the first report on YTX-production in shelf waters of Argentina
}

\author{
Rut Akselman $^{\mathrm{a}, *}$, Bernd Krock ${ }^{\mathrm{b}}$, Tilman J. Alpermann ${ }^{\mathrm{c}}$, Urban Tillmann ${ }^{\mathrm{b}}$, \\ C. Marcela Borel ${ }^{\mathrm{d}}$, Gastón O. Almandoz ${ }^{\mathrm{e}}$, Martha E. Ferrario ${ }^{\mathrm{e}}$ \\ ${ }^{a}$ Instituto Nacional de Investigación y Desarrollo Pesquero-INIDEP, V. Ocampo 1, Escollera Norte, B7602HSA Mar del Plata, Argentina \\ ${ }^{\mathrm{b}}$ Alfred Wegener Institute for Polar and Marine Research, Am Handelshafen 12, D-27570 Bremerhaven, Germany \\ ' Senckenberg Research Institute and Natural History Museum, Senckenberganlage 25, D-60325 Frankfurt a.M., Germany \\ ${ }^{\mathrm{d}}$ Instituto Geológico del Sur-INGEOSUR, CONICET-Universidad Nacional del Sur, San Juan 670, B8000ICN Bahía Blanca, Argentina \\ ${ }^{\mathrm{e}}$ Facultad de Ciencias Naturales y Museo, Paseo del Bosque s/n, 1900 La Plata, Argentina
}

\section{A R T I C L E I N F O}

\section{Article history:}

Received 1 September 2014

Received in revised form 20 March 2015

Accepted 28 March 2015

\section{Keywords:}

Protoceratium reticulatum

Dinoflagellates

Southwestern Atlantic

Phylogeny

Yessotoxins

Cysts

\begin{abstract}
A B S T R A C T
Protoceratium reticulatum is a dinoflagellate with a life cycle that includes a motile planktonic stage and a resting cyst stage in benthic habitat, both with a wide geographical distribution, including southern South America. P. reticulatum produces yessotoxins (YTX) - these can be accumulated in shellfish and show potent cytotoxicity, posing a risk to human health if contaminated shellfish is consumed. YTX have been reported from coastal shellfish of many localities, but until now it was unknown if they were present in the austral Southwestern Atlantic and also if local populations of $P$. reticulatum have the ability to produce these toxins. In this study we report the presence of YTX in plankton samples and its production in culture by two $P$. reticulatum strains isolated from the San Jorge Gulf (SJG). In addition, we describe the geographical distribution and seasonal abundance of this species based on data collected over the past two decades. The YTX cell quotas calculated from net hauls $\left(\sim 10 \mathrm{pg}\right.$ cell $\left.^{-1}\right)$ are in the same range as the toxin cell quotas observed in these two isolates. The phylogenetic analysis of sequences of the hypervariable region of the large subunit (LSU) 28S rDNA showed that the two clonal strains from the SJG were part of a monophyletic clade that subdivides $P$. reticulatum into two well-supported, divergent sub-clades. The sequences of the two strains of $P$. reticulatum from the SJG fell in the same clade as the majority of sequences of $P$. reticulatum, which belong to a geographically widely distributed evolutionary clade. P. reticulatum was occasionally observed from about $35^{\circ} \mathrm{S}$ in Uruguayan shelf waters up to $53^{\circ} \mathrm{S}$ on the Patagonian shelf and north of Tierra del Fuego, and it was present from coastal areas up to the shelf break zone. We recorded $P$. reticulatum in plankton samples during spring, summer and autumn but invariably in low abundance (maximum: 560 cells $\mathrm{L}^{-1}$ ). Viable cysts of the species in surface sediments also showed a wide geographical distribution. Together, the high total abundances and high relative numerical contribution to planktonic dinoflagellate assemblages near frontal areas, emphasize the necessity to pay attention to the dynamics of this species in areas of potential risk of harmful algal bloom development.
\end{abstract}

(c) 2015 Elsevier B.V. All rights reserved.

\section{Introduction}

Protoceratium reticulatum (Claparède et Lachmann) Bütschli, is a dinoflagellate with a life cycle that includes a motile planktonic stage and a benthic resting cyst stage. It has a complex taxonomic

\footnotetext{
* Corresponding author. Tel.: +54 2234802162.

E-mail address: rutaks@inidep.edu.ar (R. Akselman).
}

and nomenclatural history dating back to the 19th century. First described as Peridinium reticulatum by Claparède and Lachmann (1858-1859), it was later transferred to the genus Protoceratium by Bütschli (1885). After nearly a century, Reinecke (1967) described a new species, Gonyaulax grindleyi, apparently ignoring the work by Bütschli (1885) and other reports of $P$. reticulatum from European waters (e.g. Wołoszyńska, 1928). Most authors considered $P$. reticulatum and G. grindleyi as conspecific and have used either of these binomials (e.g. Steidinger and Tangen, 1996; Taylor et al., 
2004). The morphological study of Hansen et al. (1996/1997) supported conspecificity of the two taxa based on plate tabulation analysis of samples collected at a site close to the locality from which the type species of Protoceratium (P. aceros Bergh) was first described, concluding that the name Protoceratium reticulatum has priority and should therefore be used. The motile stage of $P$. reticulatum has a wide geographical distribution that comprises global coastal waters including the North Sea and the Baltic Sea, and the Mexican Pacific, the Gulf of Mexico, the Atlantic coast of North America, the east coast of Russia, New Zealand and South Africa, among other areas (e.g. Braarud, 1945; Reinecke, 1967; Steidinger and Williams, 1970; Hernández-Becerril, 1988; Hansen et al., 1996/1997; MacKenzie et al., 1998; Hällfors, 2004; Kim et al., 2004; Orlova et al., 2004). In South America, the species has been recorded in coastal waters of Argentina, Chile and Brazil (see Balech, 1988; Seguel et al., 2005; Odebrecht, 2010).

Braarud (1945) was the first author who described the spiny cysts of Protoceratium reticulatum, formed in cultures from a clone isolated in the Oslo Fjord, Norway. Wall and Dale (1968) successfully incubated cysts from recent sediments and the germinated mobile thecae were identified as Protoceratium reticulatum. The incubated cysts were recorded by these authors as identical to the Pleistocene cysts that Wall (1967) identified as Operculodinium centrocarpum. In the original description, $O$. centrocarpum (as Hystrichosphaeridium centrocarpum) from the Miocene appeared as a species with processes of 13-18 $\mu \mathrm{m}$ length, solid, showing radial fibrils at the insertion point and apices widened with small curved tips (Deflandre and Cookson, 1955). Wall (1967) described specimens from the Pleistocene of the Caribbean Sea that assigned to $H$. centrocarpum but transferred the species to the genus Operculodinium. Therefore, modern and Quaternary cysts are referred to as Operculodinium centrocarpum (Deflandre et Cookson) sensu Wall, 1967. O. centrocarpum is known in the paleontological record from the Eocene to recent times, having been documented from numerous sites including Holocene sediments of the northern inner shelf and the Beagle Channel in Argentina (Borromei and Quattrocchio, 2001; Borel et al., 2006; Vilanova et al., 2008). It has been recorded in the plankton (Reid, 1978) and also has a wide geographical distribution in recent sediments (Marret and Zonneveld, 2003), being one of the most abundant species in some benthic dinocyst communities. It has been characterized as a cosmopolitan, temperate to tropical, neritic and oceanic species (e.g. Wall et al., 1977; Harland, 1983). In recent sediments from the Southwestern Atlantic it was first quoted by Wall et al. (1977) in a transect offshore off the Río de la Plata river, and it was also recorded from near coastal sites of the northern Argentine shelf (Grill and Guerstein, 1995; Akselman, 1999). Modern cysts show a great variability in process lengths and salinity and temperature have been shown to play an important role in this variation (Verleye et al., 2012).

A special interest in Protoceratium reticulatum arose toward the end of the 1990s after discovering that it produces a newly described type of toxin, the yessotoxins (YTX), responsible for shellfish toxicity (Satake et al., 1997; MacKenzie et al., 1998). Previously, it was also associated with shellfish toxicity in South African waters (Reinecke, 1967), and were suspected to be paralytic shellfish poisoning (PSP) toxins (Grindley and Nel, 1970). Yessotoxin is a lipophilic ladder shaped polyketides that was first isolated from the scallop Patinopecten yessoensis Jay after a red-tide in Japan by Murata et al. (1987). Since its discovery a growing number of YTX analogs (up to date almost 100) has been isolated and characterized from both dinoflagellates and shellfish (see e.g. Paz et al., 2013, and references therein). Yessotoxins are toxic to mice after intraperitoneal injection and show potent cytotoxicity against human tumor cell lines (Konishi et al., 2004). Yessotoxin in particular, is a powerful compound that increases permeability in rat liver mitochondria (Bianchi et al., 2004). After its discovery in Japan, YTX and its congeners were also isolated from shellfish in many coastal sites (e.g., Ciminiello et al., 1997; MacKenzie et al., 1998; Arévalo et al., 2004; Aasen et al., 2005; Quilliam et al., 2006; Morton et al., 2007; Howard et al., 2008; Belin and Zouher, 2009). In South America YTX were detected in shellfish from Chile and Brazil (Yasumoto and Takizawa, 1997; Schramm et al., 2010). Production of YTX has been shown to occur during all phases of growth in batch culture of $P$. reticulatum strains and the toxins are contained within cells as well as in the culture medium (Paz et al., 2013). Besides $P$. reticulatum, two other gonyaulacoid dinoflagellate species, Lingulodinium polyedrum (Stein) Dodge and Gonyaulax spinifera (Claparède et Lachmann) Diesing, have been shown to also produce YTX (Tubaro et al., 1998; Draisci et al., 1999; Rhodes et al., 2006). Lingulodinium polyedrum and Gonyaulax spinifera are also present in the Southwest Atlantic (Balech, 1988). However, it still was unknown if YTX are present in waters of the austral Southwest Atlantic and also if Protoceratium reticulatum and/or L. polyedrum and G. spinifera have the ability to produce these toxins in this region.

In this study we report on the first detection of YTX in natural phytoplankton samples from the Southwest Atlantic and present YTX profiles of strains of Protoceratium reticulatum isolated from the San Jorge Gulf (SJG). A phylogenetic analysis of the hypervariable region of the large subunit (LSU) ribosomal gene was carried out to assess the genetic relationships between the South American isolates and other isolates. We also compiled data collected over the past two decades on the distribution and seasonal abundance of this species in the region and present information on the distribution of resting cysts in plankton samples and surface sediments collected in various sectors of the coastal shelves of the Southwest Atlantic.

\section{Materials and methods}

\subsection{Field collection of plankton and sediments. Hydrographic data}

Sampling procedures were performed on board research cruises conducted to the time-series station Estación Permanente de Estudios Ambientales - EPEA(Permanent Station of Environmental Studies, $\sim 15 \mathrm{nmi}$ off Mar del Plata, $\sim$ monthly intervals from May 1994 to April 1995), the Southern Patagonian shelf (March-April 2000 and 2004, cruises EH-03-00 and EH-03-04, respectively), the Argentine-Uruguayan Common Fishing Zone (AUCFZ) (November 2001, EH-09-01), the shelf break area and Southern Patagonian shelf (October 2005, March-April 2006, PD-GEF Patagonia 1 and 2, respectively), the Patagonian littoral and San Jorge Gulf (January 2010, OB-01-10), a sampling in the Beagle Channel, Tierra del Fuego Island (March 2012), and a cruise from the Beagle Channel to Mar del Plata (March-April 2012, PD Patagonia Austral 2012). Surface sediment sampling was also conducted at the port of Mar del Plata and the neighboring coastal localities of Chapadmalal and Miramar in January 1986 (Fig. 1, and Supplementary Material: Table 1, Fig. 1).

Supplementary Fig. S1 related to this article can be found, in the online version, at doi:10.1016/j.hal.2015.03.001.

Supplementary Table S1 related to this article can be found, in the online version, at doi:10.1016/j.hal.2015.03.001.

For quantitative analysis of phytoplankton, water samples were collected with Niskin bottles at standard depths in cruises to the EPEA station, the AUCFZ and the Southern Patagonian shelf, while three depths were sampled according to the fluorometric profile (surface, at fluorescence maximum and at a selected depth within the stratum below) in cruises to the shelf break area and Southern Patagonian shelf. These samples were preserved with Lugol's 


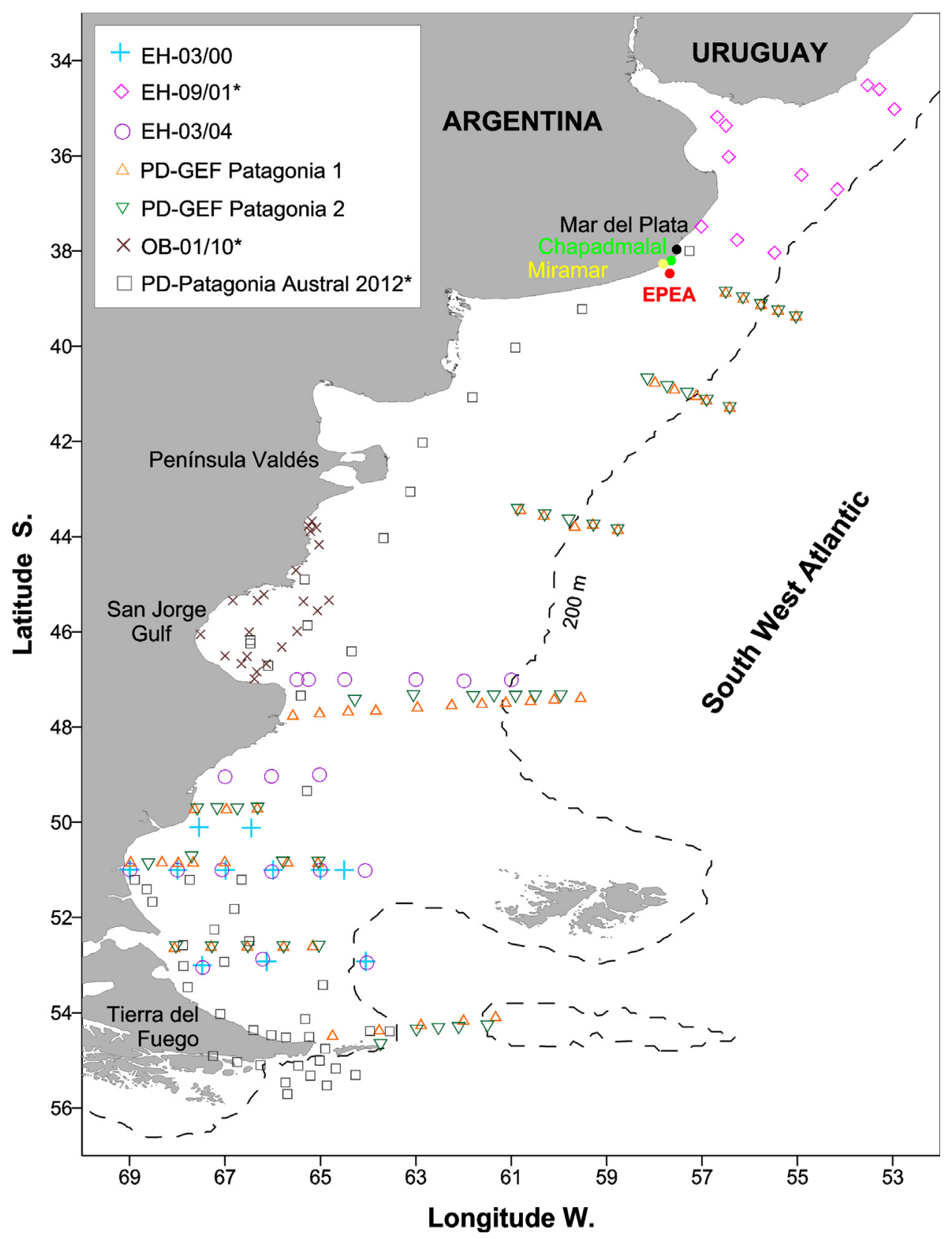

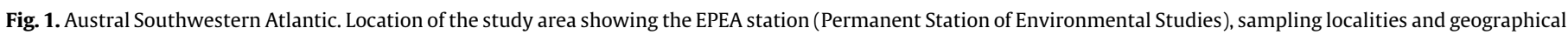

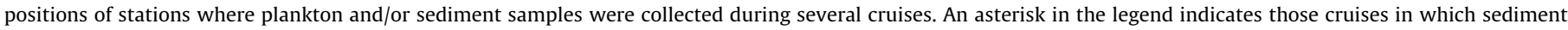
samples were collected.

solution. During the cruise from the Beagle Channel to Mar del Plata, vertical net tows were conducted at each station through the upper $20 \mathrm{~m}$ of the water column with a $20 \mu \mathrm{m}$-mesh Nitex plankton net. Net hauls were adjusted to a volume of $1 \mathrm{~L}$ with filtered $(3 \mu \mathrm{m})$ sea water and an aliquot of $20 \mathrm{~mL}$ was fixed with $0.4 \mathrm{~mL}$ of Lugol's solution.

Different sampling devices were used to collect sediments for dinoflagellate cyst studies: a Piccard dredge, a snapper and a manually operated grab bucket (Supplementary material Table 1). The first two centimeters were collected for analysis from the snapper and grab bucket samplers, while representative aliquots were collected from dredge samples. Surface samples were obtained from the top centimeter of box coring sediments collected during cruises to the Patagonian littoral zone and SJG, and from the Beagle Channel to Mar del Plata. Sediment samples were kept in dark cool $\left(4^{\circ} \mathrm{C}\right)$ conditions to prevent cyst germination until analysis.

Temperature and salinity profiles were measured with a CTD (Seabird SBE 19).

\subsection{Plankton analysis}

Identification and enumeration of cells in quantitative plankton samples were done following the Utermöhl method (Hasle, 1978) with an Olympus IX70 inverted microscope coupled to an image capture system (CCD-RGB camera, Sony DXC 151A). Subsamples of vertical net tows (see Section 2.6 for plankton collection and size-fractionation) were counted in duplicates in Sedgewick-Rafter chambers, using a phase contrast LEICA DMIL LED inverted microscope. The whole chamber bottom was scanned at 
$200 \times$ magnification. Additional qualitative observations were done by UV epifluorescence microscopy (Leica DM 2500) of thecal plates stained with Calcofluor according to Fritz and Triemer (1985). Moreover, selected subsamples were mounted onto glass stubs and sputter coated with $\mathrm{Au}-\mathrm{Pd}$ following procedures by Ferrario et al. (1995), and examined by scanning electron microscopy (Jeol JSM-6360 LV). Author names of algal species was used according to Guiry and Guiry (2014).

\subsection{Dinoflagellate cyst analysis from surface sediments}

Different processing methods for sediments were used to analyze dinoflagellate cyst assemblages according to the cruise under consideration.

During cruises to the EPEA station, the AUCFZ and the Patagonian littoral and SJG, an aliquot $\left(3 \mathrm{~cm}^{3}\right)$ of sediment from each station was sonicated for $1 \mathrm{~min}$ and subsequently sieved through gauze of $125 \mu \mathrm{m}$ and $25 \mu \mathrm{m}$ mesh size with filtered seawater. The $25-125 \mu \mathrm{m}$ size fraction was resuspended in a known volume of filtered seawater and neutralized formaldehyde solution. A Sedgewick-Rafter chamber was used for cyst enumeration and a minimum of 250 dinocysts was counted per sample. Abundance was expressed in cysts $\mathrm{cm}^{-3}$ of wet sediment. Cyst assemblages processed by this method included organic-walled and calcareous cysts.

A qualitative analysis of Protoceratium reticulatum cysts (presence/absence) was done for samples from coastal localities. During the cruise from the Beagle Channel to Mar del Plata, an aliquot (5$10 \mathrm{~g}$ wet weight) of sediment from each station was sieved through $150 \mu \mathrm{m}$ and $10 \mu \mathrm{m}$ Nitex ${ }^{\mathbb{R}}$ screens, and one calibrated tablet of Lycopodium spores was added in each sample as exotic markers (Stockmarr, 1971) to allow calculations of concentrations in cysts $\mathrm{g}^{-1}$ of wet sediment. The fraction between 10 and $150 \mu \mathrm{m}$ was treated with cold $10 \%$ hydrochloric acid. Zinc chloride was used as heavy liquid to separate the organic fraction by density gradient. Residues were sieved and collected on a $10-\mu \mathrm{m}$ mesh and then mounted between slide and cover-slide in glycerine jelly. Organicwalled dinoflagellate cysts ("dinocysts") were identified using a transmitted-light microscope (Nikon Eclipse 600) at a magnification factor of $600 \times$ and $1000 \times$ and a minimum of 250 dinocysts was counted per sample. Permanent slides (LPUNS-PA) are stored at the Colección Palinológica, Laboratorio de Palinología (INGEOSUR-UNS), Bahía Blanca, Argentina.

\subsection{Isolation and culturing}

At station C43 (PD Patagonia Austral 2012 Cruise, see Supplementary material Table 1 for geographic position) $100 \mathrm{~mL}$ of sea water from $3 \mathrm{~m}$ depth were filled into a PE flask and kept at $4{ }^{\circ} \mathrm{C}$ until inspection. Single Protoceratium reticulatum cells were isolated from this sample under a stereomicroscope (Olympus SZH-ILLD) by micropipette. Cells were transferred into individual wells of 96-well tissue culture plates (TPP, Trasadingen, Switzerland) containing $300 \mu \mathrm{L}$ of K medium (Keller et al., 1987), prepared from $0.2 \mu \mathrm{m}$ sterile-filtered natural Antarctic seawater in $1 / 10$ of the original concentration. Isolated cells were then incubated at $15{ }^{\circ} \mathrm{C}$ under artificial light at a photon flux density of $50 \mu \mathrm{mol}$ photons $\mathrm{m}^{-2} \mathrm{~s}^{-1}$ on a 16:8 light:dark photocycle. After 3-4 weeks, two unialgal isolates (provisionally named A2 and H1) were transferred to polystyrene cell culture flasks each containing $50 \mathrm{~mL}$ of $1 / 2$ strength $\mathrm{K}$ medium and were maintained thereafter under the same conditions as described.

For toxin analysis, two cultures for each strain were grown at two different dates in $70 \mathrm{~mL}$ polystyrene cell culture flasks at the same environmental conditions as described before. Cell density was determined by settling lugol-fixed samples and counting
$>800$ cells under an inverted microscope. Dense cultures (cell concentration: $8,510 \mathrm{~mL}^{-1}$ and $16,791 \mathrm{~mL}^{-1}$ for $\mathrm{A} 2 ; 10,930 \mathrm{~mL}^{-1}$ and $18,909 \mathrm{~mL}^{-1}$ for $\mathrm{H} 1$ ) were harvested in $50 \mathrm{~mL}$ Falcon tubes by centrifugation (Eppendorf 5810R, Hamburg, Germany) at 3,220 $\times g$ for $15 \mathrm{~min}$. Each pellet was transferred to an Eppendorf microtube and again centrifuged (Eppendorf $5415,16,000 \times \mathrm{g}, 5 \mathrm{~min}$ ) and stored frozen $\left(-20^{\circ} \mathrm{C}\right)$ until use. Yessotoxins were analyzed separately for each pellet and cell quota for each strain was calculated as a mean of both cell pellets.

For molecular genetic analysis, one culture for each isolate was grown and harvested exactly as described before. Cell concentrations at harvest time in this case were $4,440 \mathrm{~mL}^{-1}$ for strain A2 and $10,610 \mathrm{~mL}^{-1}$ for strain $\mathrm{H} 1$, respectively. Cell pellets for sequence analysis were also stored at $-20{ }^{\circ} \mathrm{C}$ until use.

\subsection{Molecular phylogenetic analysis}

Cell pellets were used to extract DNA with the DNeasy Plant Mini Kit (Qiagen, Hilden, Germany) according to the manufacturer's instructions and as detailed in Töbe et al. (2013). Resulting genomic DNA was used in PCR to amplify the D1/D2 hypervariable region of the large sub-unit (LSU) of the ribosomal operon with the primers D1R (forward) and D2C (reverse) (Scholin et al., 1994) and PCR chemistry and cycling conditions as in Töbe et al. (2013). Products of PCR were purified with a QIAquick PCR Purification Kit (Qiagen, Hilden, Germany) and used in Sanger sequencing with the same primers as in PCR with a BigDye ${ }^{\circledR}$ Terminator v3.1 Cycle Sequencing Kit (Applied Biosystems, Darmstadt, Germany). After clean-up of sequencing reaction products with a DyeEx 2.0 Spin Kit (Qiagen), the sequences were read on an ABI 3130XL Genetic Analyzer (Applied Biosystems). Primer sequences were removed from contigs after assembly of forward and reverse sequences in Geneious Pro 5.4.4 (Biomatters Ltd., Auckland, New Zealand). A BLAST search was conducted with the sequences of isolates $\mathrm{H} 1$ and $A 2$ and the resultant D1/D2 region LSU sequences of other Protoceratium reticulatum isolates were retrieved from GenBank. Sequences of $P$. reticulatum and a set of other sequences were aligned in MAFFT v7.017 using a plugin for Geneious Pro. The additional sequences corresponded to those that were used to analyze phylogenetic relationships among gonyaulacoid dinoflagellates in Howard et al. (2009) and an additional set of sequences representing the five ribotypes of the Alexandrium tamarense/A. fundyense/A. catenella species complex (Supplementary material Table 2, Bolch and de Salas, 2007; Daugbjerg et al., 2000; Ellegaard et al., 2003; Herrera-Sepúlveda et al., 2013; Higman et al., 2001; Kim et al., 2006; Kim and Kim, 2007; Mertens et al., 2012; Orr et al., 2011; Riccardi et al., 2006; Ruiz Sebastián and O'Ryan, 2001; Scorzetti et al., 2009; Walsh et al., 1998). A sequence of Prorocentrum minimum was included as outgroup. The resultant alignment was restricted to the length of the sequences of isolates $\mathrm{H} 1$ and $\mathrm{A} 2$ and the best fitting model of nucleotide substitution was determined according to scores of the Akaike Information Criterion in jModeltest 0.1.1 (Guindon and Gascuel, 2003; Posada, 2008). A Maximum Likelihood (ML) tree was constructed using the GTR + G model of nucleotide substitution in PhyML (Guindon and Gascuel, 2003) via a plugin in Geneious Pro. Reliability of tree topology was estimated by 200 bootstrap replicates.

Supplementary Table S2 related to this article can be found, in the online version, at doi:10.1016/j.hal.2015.03.001.

\subsection{Chemical analysis of yessotoxins}

For plankton collection and size-fractionation, vertical net tow concentrates of stations from the PD-Patagonia Austral 2012 cruise (Supplementary material Table 1 ) were sequentially filtered 
through Nitex ${ }^{\circledR}$ meshes of 200,50 and $20 \mu \mathrm{m}$ by gravity filtration and each size fraction was split into aliquots. One aliquot was used for the extraction of lipophilic toxins.

For toxin extraction from plankton, the cell pellets from the 50 to $20 \mu \mathrm{m}$ aliquots of the plankton net tows and Protoceratium reticulatum cultures were harvested by centrifugation $\left(3,220 \times g, 15 \mathrm{~min}\right.$ at $\left.4{ }^{\circ} \mathrm{C}\right)$, suspended in $500 \mu \mathrm{L}$ methanol for lipophilic toxins, and subsequently transferred into a FastPrep tube containing $0.9 \mathrm{~g}$ of lysing matrix D (Thermo Savant, Illkirch, France). The samples were homogenized by reciprocal shaking at maximum speed $\left(6.5 \mathrm{~m} \mathrm{~s}^{-1}\right)$ for $45 \mathrm{~s}$ in a Bio101 FastPrep instrument (Thermo Savant, Illkirch, France). After homogenization, samples were centrifuged at $16,100 \times \mathrm{g}$ at $4{ }^{\circ} \mathrm{C}$ for $15 \mathrm{~min}$. The supernatant was transferred to a spin-filter ( $0.45 \mu \mathrm{m}$ pore-size, Millipore Ultrafree, Eschborn, Germany) and centrifuged for $30 \mathrm{~s}$ at $800 \times \mathrm{g}$, followed by transfer to autosampler vials.

Field samples were analyzed for multiple lipophilic toxins as described in Krock et al. (2008b). Mass spectrometric analyses of Protoceratium reticulatum isolates for YTX were performed on a Hypersil BDS C8 column $(50 \times 2 \mathrm{~mm}, 3 \mu \mathrm{m}, 120 \mathrm{~A})$ at a flow rate of $0.3 \mathrm{~mL} \mathrm{~min}^{-1}$ using an elution gradient with two eluants (A: water and B: 95\% acetonitrile/methanol (1:2, v/v) and 5\% water, both eluants containing $2.0 \mathrm{mM}$ ammonium formate and $50 \mathrm{mM}$ formic acid). Initial composition was $40 \% \mathrm{~B}$ with a linear gradient to $100 \%$ B at $6 \mathrm{~min}$, isocratic $100 \%$ B until $15 \mathrm{~min}$, then returning to initial conditions. Selected transitions (precursor ion $>$ fragment ion) are given in Supplementary material Table 3. Yessotoxin was identified by its mass transitions and comparison of retention times of samples and a reference standard (IMB-NRC, Halifax, Canada). Relative abundances are based on peak area comparisons, identical response factors for all transitions are assumed.

Supplementary Table S3 related to this article can be found, in the online version, at doi:10.1016/j.hal.2015.03.001.

\section{Results}

\subsection{Thecal and cyst morphology}

Cells of Protoceratium reticulatum analyzed from water samples (EH-03-04 (St 256) and the EPEA station) showed morphological characteristics (Balech, 1971, as Gonyaulax grindleyi) which briefly were the following: subsphaeroidal with the longitudinal axis greater than the transverse, without neck and spines; epitheca shorter than hypotheca; cingulum displacement of 1-2 times its width, descendent, without overhanging; sulcus narrow, excavated; dark wall with a marked reticulated sculpture, raised ridges and a pore in each polygon; and the first apical plate with a prominent ventral pore on its right side (Fig. 2A-C). Plate formula: Po, 3', 1a, 6",

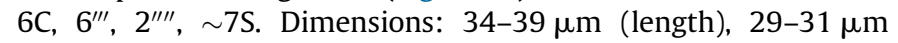
(transdiameter) ( $n=20$ cells). Its cysts (Matsuoka, 1985) were spherical, transparent, with hollow processes of variable length which were capitate or cylindrical with closed extremities; precingular archeopyle at the third paraplate, operculum free (Fig. 2D-F). Diameter (without processes): 35-45 $\mu \mathrm{m}$ ( $n=15$ cysts).

\subsection{Phylogenetic analysis}

The Maximum Likelihood (ML) analysis of the hypervariable region of the large subunit (LSU) 28S rDNA showed that the sequences obtained from the two clonal strains $\mathrm{A} 2$ and $\mathrm{H} 1$ from the SJG were identical to each other and to other sequences of Protoceratium reticulatum strains included in the multiple sequence alignment (Fig. 3). In the present ML tree, all P. reticulatum were part of a monophyletic clade that further subdivides into two well supported, divergent sub-clades. The sequences of the two clonal strains isolated in this study fell in the same clade as the majority of sequences of $P$. reticulatum and only three isolates of $P$. reticulatum from the west and east coasts of USA (Supplementary material Table 2) comprised the second sub-clade within P. reticulatum.
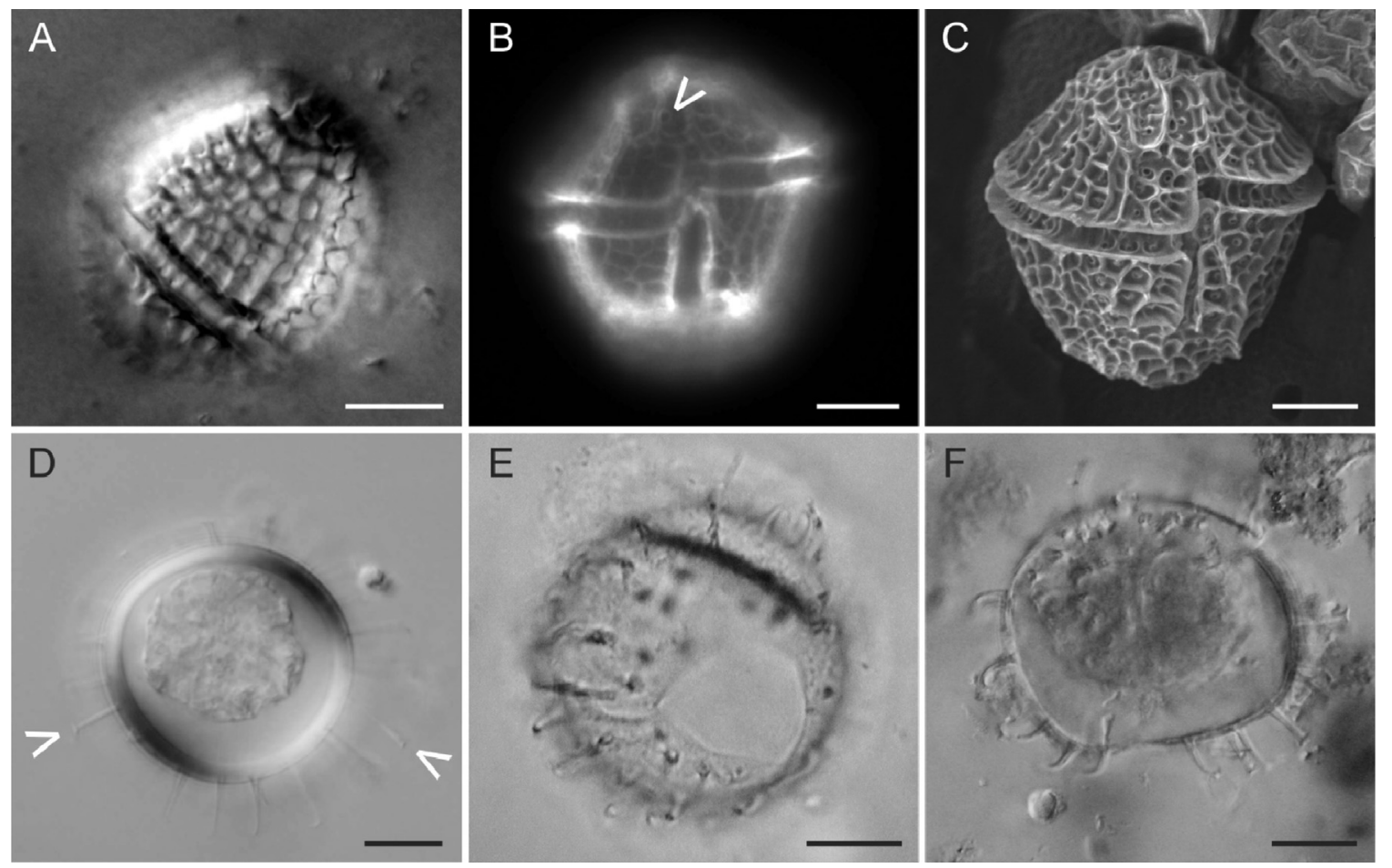

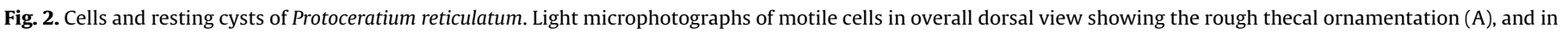

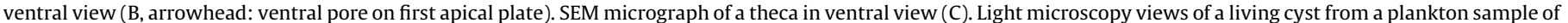

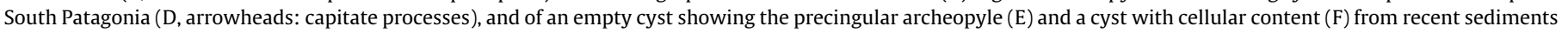
of the San Jorge Gulf. Bars: $10 \mu \mathrm{m}$. 


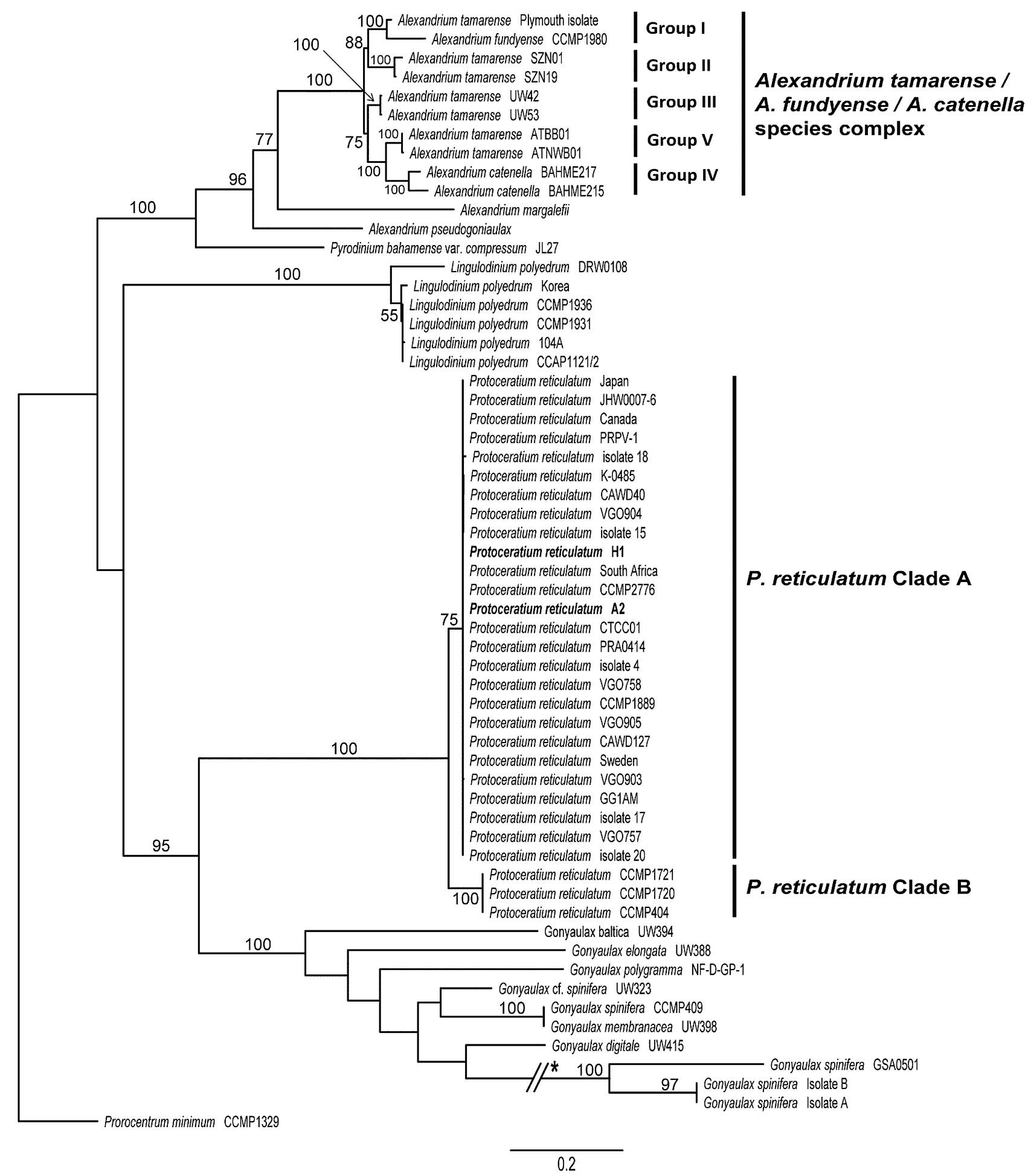

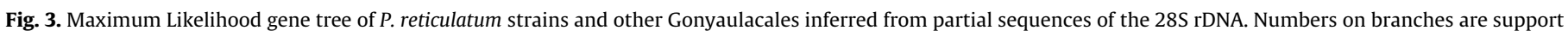

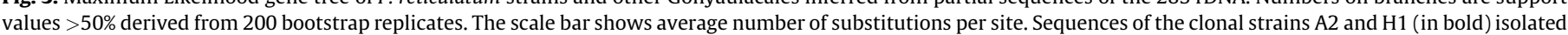

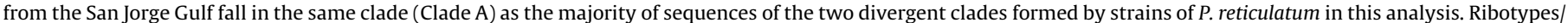

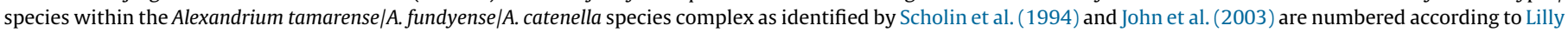
et al. (2007). * original branch length: 0.88 .

\subsection{Spatial distribution, abundance and seasonal occurrence of the motile cell stage}

We found motile cells of Protoceratium reticulatum throughout a broad latitudinal distribution ranging from $34.52^{\circ} \mathrm{S}$ in Uruguayan shelf waters up to $52.63^{\circ} \mathrm{S}$ at the southern shelf in Argentina (Fig. 4). Geographic distribution encompassed the AUCFZ including the mouth of the Río de la Plata up to the Magellan Strait and north of Tierra del Fuego, covering the northern Argentine shelf and central and southern Patagonia. P. reticulatum also showed a wide distribution across the shelf, being present at latitudes of $38-40^{\circ} \mathrm{S}$ from near the coast at the EPEA station ( $\sim 48 \mathrm{~m}$ depth) up to the shelf break area (max. depth $\sim 1529 \mathrm{~m}$ ), and at $\sim 45-47^{\circ} \mathrm{S}$ from the SJG, where it was recorded in net haul samples (PD-Patagonia 


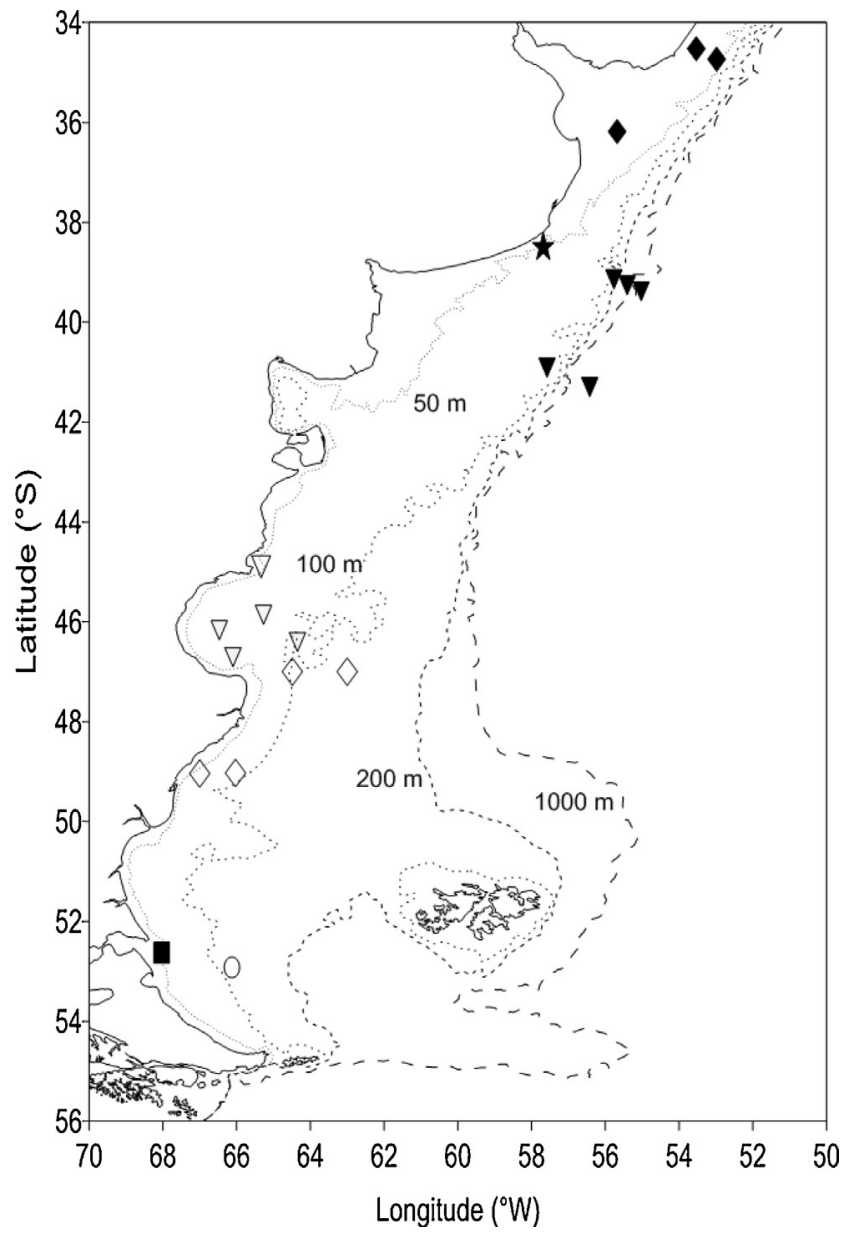

Fig. 4. Geographic distribution of the motile stage of $P$. reticulatum at the austral Southwestern Atlantic. Symbols correspond to the EPEA station $(\star)$ and analyzed cruises ( $\bigcirc$ : EH-03-00; $\diamond$ : EH-09-01; $\diamond:$ EH-03-04; $\nabla$ : PD GEF Patagonia 1; $\mathbf{\square}$ : PD GEF Patagonia 2; $\nabla$ : PD Patagonia Austral 2012).

Austral 2012), to the central shelf. Despite its large spatial distribution, $P$. reticulatum was recorded only sporadically in quantitative samples collected during the five analyzed cruises of sufficient spatial coverage (EH-03-00, EH-09-01, EH-03-04, PDGEF Patagonia 1 and PD-GEF Patagonia 2). Indeed, in the cruise to the AUCFZ area, $P$. reticulatum was registered at 3 out of the 12 analyzed stations, while in cruises which have covered the shelf break area between $\sim 39^{\circ}$ and $44^{\circ} \mathrm{S}$ and the Southern Patagonian shelf between $47^{\circ}$ and $55^{\circ} \mathrm{S}$, it was recorded in 5 of 30 and in 6 of 90 stations respectively. $P$. reticulatum was also detected only once during the sampling period at the EPEA station.

Abundance of Protoceratium reticulatum was invariably low in all the examined plankton samples, and its cells were registered in different depths of the water column. Quantitative estimations showed a maximum abundance of 560 cells $\mathrm{L}^{-1}$, but values of $\sim 100$ cells $\mathrm{L}^{-1}$ were frequently observed. In some cases, although not detected in bottle samples, its cells were registered in plankton net samples.

The seasonal occurrence of the motile stage was analyzed at the EPEA station during the period from May 1994 to April 1995. Bottle samples collected at standard depths in 12 cruises showed that Protoceratium reticulatum appeared only once, in January 1995 (i.e. in summer at the Southern Hemisphere), and in low abundance (max. 260 cells $\mathrm{L}^{-1}$ ) in the water column. Moreover, it was recorded only in samples collected during cruises conducted in spring (EH-09/01, PD-GEF Patagonia 1) and autumn (EH-03/00,
EH-03/04, PD-GEF Patagonia 2, PD-Patagonia Austral 2012). It should be noted that the data analyzed were from a database of species present in cruises conducted at different seasonal periods, with data selected for the occurrence of $P$. reticulatum. Both sources of information suggest that in the austral Southwest Atlantic region $P$. reticulatum cells were present in the warm period of the year.

Surface salinity and temperature values associated to the presence of Protoceratium reticulatum in plankton samples spanned ranges of $23-34.1$ and $6.8-20.3^{\circ} \mathrm{C}$, respectively. These values represent not only hydrographic conditions of the different water masses but also the whole period of spring, summer and autumn during which the species was recorded. The lower salinity was recorded at the mouth of the Río de la Plata, while low values were also determined north of the river in Uruguayan shelf waters (30-32.1), at the Magellan Strait (32.8-33.2), and in southern Patagonia (32.9-33.1). At the shelf break area P. reticulatum was present in high salinity (33.9-34.1) and low temperature waters $\left(6.8-7.3^{\circ} \mathrm{C}\right)$.

\subsection{Spatial distribution and abundance of resting cysts}

Resting cysts of Protoceratium reticulatum in surface sediments were recorded in shelf areas at the AUCFZ, the EPEA station, the Patagonic littoral north of $45^{\circ} \mathrm{S}$ and the SJG, as well as in the three coastal localities sampled at northern Argentine shelf, spanning a latitudinal range from $34.52^{\circ} \mathrm{S}$ to $46.67^{\circ} \mathrm{S}$ and from the coast to near the $200 \mathrm{~m}$ isobath (Fig. 5).

At the EPEA, resting cysts with cellular content or viable cysts, as well as empty cysts of Protoceratium reticulatum were identified all throughout the annual period, being present in sediments from the 12 analyzed cruises (Table 1). Its abundance ranged from 8 to 470 cysts $\mathrm{cm}^{-3}$ wet sediment, and its percentage from $0.8 \%$ to $35 \%$ in viable dinoflagellate cyst assemblages. Viable cyst concentration were high with an average value of 94 cysts $\mathrm{cm}^{-3}$ wet sediment and an average percentage of $10.9 \%$ of the whole assemblage of dinoflagellate cysts. This high variability of cyst abundance at small spatial scale showed a significant negative correlation to the size grain of sediments, i.e. higher cyst concentration in sediments with smaller sediment grains ( $R$. Akselman, unpubl. results). These results from the EPEA show that although there was a latent potential ability of benthic cysts to inoculate the water column throughout the year, detection of planktonic cells was scarce, however both in number and the period in which they were detected. In addition to $P$. reticulatum, viable cysts of Lingulodinium polyedrum and species of Gonyaulax of the Gonyaulax spinifera complex were also present, among other species.

Qualitatively analyzed samples at the coastal localities of Mar del Plata, Chapadmalal and Miramar showed only empty cysts of Protoceratium reticulatum.

Abundance of viable Protoceratium reticulatum cysts at the AUCFZ ranged $16-4,368$ cysts $\mathrm{cm}^{-3}$ wet sediment with percentages of $11-83 \%$ in dinoflagellate cysts assemblages (Table 1). $P$. reticulatum cysts were recorded in sediments from the three transects, at the Uruguayan and Argentinian shelves and at the boundary line facing the Río de la Plata. High concentrations $\left(\geq 1,000\right.$ cysts $\mathrm{cm}^{-3}$ wet sediment) and a marked variability were shown in each transect, with the highest value at the Río de la Plata (St 802). In this area and regardless of their abundance, $P$. reticulatum cysts constituted an important fraction with values generally $\geq 30 \%$ of all dinoflagellate cysts. In addition to $P$. reticulatum, live cysts of Lingulodinium polyedrum were recorded among other species in assemblages at the AUCFZ.

At the Patagonian littoral north of $45^{\circ} \mathrm{S}$ and at the SJG, estimates made in samples processed without acid treatment, viable cyst concentration of Protoceratium reticulatum ranged $20-2,933$ cysts $\mathrm{cm}^{-3}$ wet sediment and attained percentages of 


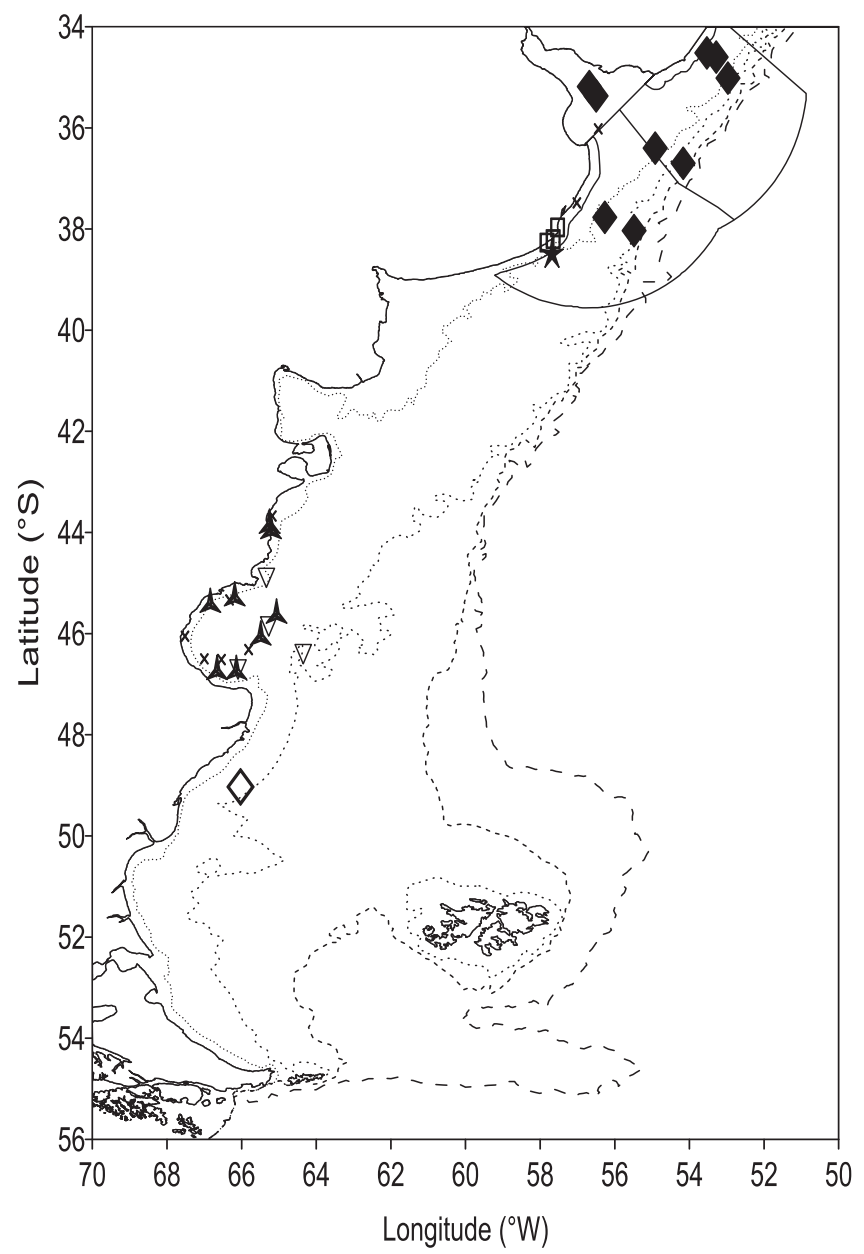

Fig. 5. Geographic distribution of $P$. reticulatum cysts at the austral Southwestern Atlantic. Symbols correspond to the EPEA station $(\star)$, the coastal localities of Mar del Plata, Chapadmalal and Miramar $(\square)$ and the analyzed cruises ( $\bullet$ : EH-09-01; $\diamond$ : EH-03-04: $\nabla$ : PD Patagonia Austral 2012; A : OB-01-10). All data points correspond to surface sediments, with exception of the EH-03-04 cruise where the record came from plankton samples. $\times$ : stations at which $P$. reticulatum was not found.

$2-33 \%$ in assemblages of calcareous and organic-walled dinoflagellate cysts (Table 1). In this area, as well as in the AUCFZ, there were locations (OB-01-10 cruise, St 2, 19) at which both cysts concentration and relative frequencies were high, suggesting the relative importance of $P$. reticulatum over others in its potential capacity to inoculate the water column. Sediment samples processed by palynological treatment, which gives information on organic walled cysts (dinocysts), showed $P$. reticulatum

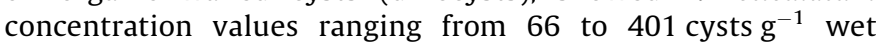
sediment (Table 1). Spatial distribution of dinocysts seemed to be heterogeneous, possibly due to the sediment grain size, as the highest concentration corresponds to muddy sediments (silty clay) and the lowest value to sites with an important fraction of sabulitic and sandy sediments (C.M. Borel, unpubl. results). Cysts of $P$. reticulatum were recorded in sediment samples from stations at which its motile cells and yessotoxins were detected simultaneously. Cysts of the Gonyaulax spinifera complex were dominant at the four analyzed stations from the PD-Patagonia Austral 2012 cruise (Table 1).

Moreover, viable Protoceratium reticulatum cysts were observed in plankton samples collected at higher latitude in south Patagonia (EH-03-04, St 256) (Figs. 2A and 5). At this position resting cysts were simultaneously observed with cells in water samples. These
Table 1

Resting cysts of $P$. reticulatum in surface sediments from cruises conducted to the EPEA station during the period May 1994-April 1995, the AUCFZ (EH-09-01) and the Patagonian shelf (OB-01-10, PD Patagonia Austral 2012). Cyst concentration in cruises to the EPEA station, EH-09-01 and OB-01-10: cysts $\mathrm{cm}^{-3}$ wet sediment; to the PD Patagonia Austral 2012: cysts ${ }^{-1}$ wet sediment. Relative abundance in cruises EH-09-01 and OB-01-10: in assemblages of calcareous and organic-walled dinoflagellate cysts; in PD Patagonia Austral 2012: in assemblages of organicwalled dinoflagellate cysts.

\begin{tabular}{|c|c|c|c|}
\hline Cruise & Station & Cyst abundance & Cyst percentage \\
\hline EH-03/94 & EPEA & 10 & 14 \\
\hline EH-04/94 & EPEA & 60 & 7 \\
\hline EH-06/94 & EPEA & 8 & 11 \\
\hline EH-08/94 & EPEA & 15 & 0.8 \\
\hline OB-06/94 & EPEA & 470 & 35 \\
\hline OB-08/94 & EPEA & 22 & 1 \\
\hline OB-09/94 & EPEA & 84 & 17 \\
\hline OB-11/94 & EPEA & 14 & 2 \\
\hline $\mathrm{EH}-01 / 95$ & EPEA & 102 & 9 \\
\hline EH-03/95 & EPEA & 305 & 17 \\
\hline OB-04/95 & EPEA & 23 & 10 \\
\hline OB-06/95 & EPEA & 14 & 7 \\
\hline EH-09-01 & 826 & 16 & 40 \\
\hline EH-09-01 & 825 & 80 & 11 \\
\hline EH-09-01 & 822 & 1,120 & 37 \\
\hline EH-09-01 & 811 & 260 & 83 \\
\hline EH-09-01 & 809 & 346 & 33 \\
\hline EH-09-01 & 802 & 4,368 & 26 \\
\hline EH-09-01 & 800 & 216 & 30 \\
\hline EH-09-01 & 792 & 1,000 & 40 \\
\hline EH-09-01 & 795 & 57 & 50 \\
\hline OB-01-10 & 2 & 1,467 & 24 \\
\hline OB-01-10 & 4 & 139 & 10 \\
\hline OB-01-10 & 9 & 106 & 2 \\
\hline OB-01-10 & 11 & 111 & 20 \\
\hline OB-01-10 & 19 & 2,933 & 33 \\
\hline OB-01-10 & 29 & 889 & 10 \\
\hline OB-01-10 & 35 & 367 & 10 \\
\hline OB-01-10 & 36 & 20 & 2 \\
\hline PD Patagonia Austral 2012 & C43 & 66 & 11 \\
\hline PD Patagonia Austral 2012 & $\mathrm{C} 45$ & 247 & 13 \\
\hline PD Patagonia Austral 2012 & $\mathrm{C} 43 \mathrm{~N}$ & 401 & 2.5 \\
\hline PD Patagonia Austral 2012 & P45B & 218 & 11 \\
\hline
\end{tabular}

cysts seemed of recent formation and not resuspended from sediments (i.e. they had no detritus attached), coincided with the maximum cell abundance ( 560 cells $\mathrm{L}^{-1}$ ) estimated in all the analyzed cruises, and were recorded together with motile cells in all levels of the water column, observations which suggest that encystment could have been occurring.

\subsection{Toxin measurements}

No YTX was detected in samples from the 21 sampling points in the Beagle Channel (March 2012). Along the entire PD 2012 transect from Ushuaia to Mar del Plata, YTX was only detected at five stations in the SJG region: C43, C43N, I44, C45 and P45B (Table 2) at concentrations ranging from $24 \mathrm{ng}$ net haul ${ }^{-1}$ at station $\mathrm{P} 45 \mathrm{~B}$ up to 343 ng net haul ${ }^{-1}$ at station I44. The yessotoxin cell quotas ranged from 4.9 to $12.7 \mathrm{pg} \mathrm{cell}^{-1}$ which were calculated from the total YTX in these $20-50 \mu \mathrm{m}$ size fractions of the net hauls and the Protoceratium reticulatum cell abundances in the respective samples (Table 2 ).

The two strains of Protoceratium reticulatum A2 and $\mathrm{H} 1$ isolated from water samples collected at station C43 had YTX cell quotas of $9.1 \mathrm{pg}$ cell $^{-1}$ and $10.2 \mathrm{pg}$ cell $^{-1}$, respectively. The YTX profiles of both strains were dominated by yessotoxin ( $>95 \%$ ). The second most abundant YTX congener was probably 32-O-arabinofuranosyl-YTX (mass transition $\mathrm{m} / \mathrm{z} 1273>1193$ ) with a maximum relative abundance $<5 \%$, which has been described by Miles et al. (2005). However, an unambiguous identification of this and the following compounds was not possible due to the lack of reference 
Table 2

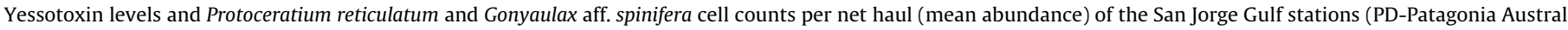
2012 cruise). Calculated cell quotas for P. reticulatum of these net hauls are also shown.

\begin{tabular}{|c|c|c|c|c|}
\hline \multirow[t]{2}{*}{ Station } & \multirow[t]{2}{*}{ YTX [ng net haul ${ }^{-1}$ ] } & \multicolumn{2}{|l|}{ Protoceratium reticulatum } & \multirow{2}{*}{$\begin{array}{l}\text { Gonyaulax aff. spinifera } \\
\text { Abundance }\left[10^{3} \text { cells net haul }{ }^{-1}\right]\end{array}$} \\
\hline & & Abundance $\left[10^{3}\right.$ cells net haul $\left.{ }^{-1}\right]$ & YTX cell quota $\left[\mathrm{pg} \mathrm{cell}^{-1}\right]$ & \\
\hline C43 & 173 & 23 & 7.5 & 0 \\
\hline $\mathrm{I} 44$ & 343 & 27.5 & 12.5 & 3.5 \\
\hline $\mathrm{C} 45$ & 197 & 40 & 4.9 & 15.5 \\
\hline $\mathrm{C} 43 \mathrm{~N}$ & 248 & 19.5 & 12.7 & 20 \\
\hline P45B & 24 & 3.5 & 7.0 & 2 \\
\hline
\end{tabular}

materials. In addition to the $m / z 1273$ compound, three other putative YTX could be detected at trace levels $<0.5 \%: \mathrm{m} / \mathrm{z}$ $1047>967$ (41-keto-YTX), $m / z 1157>1077$ (OH-YTX), and $m / z$ $1175>1095$ (diOH-YTX).

\section{Discussion}

\subsection{Taxonomy}

The motile cells of Protoceratium reticulatum analyzed herein showed morphological characteristics and plate pattern in accordance with those described by Balech (1971, as Gonyaulax grindleyi) based on samples from the Southwestern Atlantic, which also correspond to the original description of G. grindleyi made by Reinecke (1967). In our samples from the EPEA station and South Patagonia ( $\sim 10$ cells of each locality were analyzed), epithecal cell configuration of the apical and intercalary plate series were $3^{\prime}$ and $1 \mathrm{a}$, and we have not observed a plate configuration of $4^{\prime}$ and $0 \mathrm{a}$. Hansen et al. (1996/1997) showed that nearly 50\% of both plate configurations were present in natural samples from the type locality of Protoceratium aceros, the type species of Protoceratium, and concluded that $P$. reticulatum, $P$. aceros and G. grindleyi are conspecific, the first name having priority. In his monograph of the Southwest Atlantic, Balech (1988) did not consider P. reticulatum, although he had cited this species in two samples from the Productivity III cruise (Balech, 1971). In the latter study, he also simultaneously recorded $G$. grindleyi in the second of these samples, which was used for the first record and morphological description of this species in the Southwest Atlantic. The fact that Balech (1988) did not include $P$. reticulatum, but described $G$. grindleyi and considered $P$. reticulatum in its synonymy, could be interpreted by the application of his taxonomic criteria for defining sensu lato the genus Gonyaulax. The study of Hansen et al. (1996/ 1997) clarified uncertainties involved in the formal taxonomy and nomenclature regarding these taxonomic questions.

\subsection{Phylogenetic analysis}

The Maximum Likelihood tree of the LSU 28S rDNA of strains included in the multiple sequence alignment resembled with respect to the well supported clades (i.e. those with $>80 \%$ bootstrap support) the Neighbor Joining tree in Howard et al. (2009). The isolates of Protoceratium reticulatum included in the phylogenetic analysis formed a monophyletic clade that further diverged into two well supported sub-clades. The two strains of $P$. reticulatum isolated in this study, $\mathrm{A} 2$ and $\mathrm{H} 1$, belong to a geographically widely distributed sub-clade that also contained the majority of the isolates (Clade A in Fig. 3 and Supplementary material Table 2). This clade contained isolates from the western and eastern North Pacific and the western and eastern North Atlantic, including the Mediterranean. One strain from South Africa represents the eastern South Atlantic and the isolates from Argentine confirm the presence of $P$. reticulatum of Clade $A$ in the Southwest Atlantic. The second clade (Clade B in Fig. 3 and
Supplementary material Table 2 ) within $P$. reticulatum is represented by two isolates from the North American Atlantic coast (Florida) and one isolate from the North American Pacific coast (California). However, a wider geographic distribution of this clade may be confirmed as sampling efforts in other regions increase. The same may be the case for Clade A. The observed pattern of molecular diversification, with very low variation among sequences within sub-clades compared to the relatively high divergence among the two sub-clades, suggests that Clade $A$ and Clade B of $P$. reticulatum correspond to two separate evolving units. The genetic distance between these two clades is about the same as that of closely related ribotypes within the $A$. tamarense/A. fundyense/A. catenella species complex (Fig. 3). Although morphological evidence for the distinction of species in the A.tamarense/A. fundyense/A. catenella complex is still not presented, it has been widely accepted that the five ribotypes represent separate species with distinct biogeographic distribution patterns and toxin properties (Scholin et al., 1994; John et al., 2003; Lilly et al., 2007; Anderson et al., 2012; Wang et al., 2014). The same might apply to the two evolutionary clades detected in P. reticulatum. Howard et al. (2009) considered if there are genetically distinguishable isolates of $P$. reticulatum based on YTX toxicity, but found the available data insufficient to answer this question. Indeed, in all strains from Clade A yessotoxins were found with the notable exception being one strain from New Zealand (i.e., CAWD127, Fig. 3 and Supplementary material Table 2; Rhodes et al., 2006). With regard to YTX toxicity properties of strains from Clade B, Paz et al. (2004) first found all three strains to be toxic; however, a later study by Paz et al. (2007) could not detect YTX in the same strains. However, this might eventually be explained by a loss of toxicity during the respective culture conditions (Beatriz Paz, pers. comm. ${ }^{1}$ ) as a more recent study by Röder et al. (2009) again showed production of YTX in two of the same strains from Clade B previously analyzed in studies by Paz et al. (2004, 2007), i.e. CCMP404 and CCMP1720. More detailed analyses of phenotypic traits such as YTX production and mating incompatibility might show that the two ribotypic sub-clades found in P. reticulatum are indeed evolutionary entities with unique genetic and physiological properties - similar to PSP toxic and non-toxic species/ribotypes within the A. tamarense/A. fundyense/A. catenella species complex. Detailed morphological studies might even reveal recognizable characteristics allowing for species distinction. However, already at this stage, at which the two sub-clades of $P$. reticulatum can only be identified by their ribosomal sequence divergence, future studies on the species should acknowledge the existence of these clades, e.g. when investigating YTX toxicity characteristics of the isolated strains or when studying bloom dynamics of natural populations of $P$. reticulatum. This will allow determining the specific potential of these clades for harmful algal bloom development and their role in the formation of YTX toxicity episodes.

\footnotetext{
${ }^{1}$ Beatriz Paz Pino, Vigo University, Spain, beapaz@uvigo.es.
} 


\subsection{Spatial distribution, abundance and seasonal occurrence}

The motile stage of Protoceratium reticulatum was quoted previously for the Southwest Atlantic by Balech $(1971,1978)$ in a wide area which included neritic and oceanic waters in the continental shelf of Argentina, the shelf break zone and the adjacent Atlantic basin between $\sim 37^{\circ}$ and $48^{\circ} \mathrm{S}$. This study shows a more extensive geographic distribution ranging from Uruguayan shelf waters, where it has been also observed in samples from coastal monitoring programs ( $\mathrm{S}$. Méndez, pers. comm. ${ }^{2}$ ), to the mouth of the Magellan Strait. $P$. reticulatum has been found in coastal waters of Brazil including the southern states of Rio Grande and Santa Catarina (Cardoso, 1998; Odebrecht, 2010), and on the Pacific side its vegetative cells and cysts have been recorded in inshore waters of southern Chile (e.g. Seguel et al., 2005; Alves-deSouza et al., 2008). We found $P$. reticulatum in a set of temperature and salinity values which include the previous regional records (Balech, 1971, 1978; Cardoso, 1998). It was recorded in neritic and estuarine environments, as is described by Steidinger and Tangen (1996), at the mouth of the Río de la Plata and off Uruguay over shelf areas of low salinity from riverine origin, and also in pelagic waters near the shelf break in a range of hydrographic conditions which comprised different water masses including the Malvinas Current (Carreto et al., 1995; Guerrero and Piola, 1997; Acha et al., 2004). Our quantitative estimations invariably showed low abundances of $P$. reticulatum. On occasions it was only present in net plankton hauls as a rare species. A low abundance generally was also observed by Balech $(1971,1978)$ in net plankton samples. Despite documentation as a member of planktonic communities, this species usually shows low population values (e.g. Steidinger and Williams, 1970; Seguel et al., 2005; Aasen et al., 2005), although a few records of red tides were mentioned by Reinecke (1967) and MacKenzie et al. (1998). We recorded the motile stage of $P$. reticulatum from spring to autumn, i.e. throughout the warmer period of the year, in accordance with previous records from the Southwest Atlantic (Balech, 1971, 1978; Cardoso, 1998) and the Kattegat (Hansen et al., 1996/1997). It is remarkable that during the annual study at the EPEA station the motile cells were recorded only once, in summer, meanwhile the viable resting cyst stage was present in surface sediments throughout the year. A spatiotemporal progress from north to south in the presence of the motile stage in accordance with the advance of the warm season is suggested by the distribution patterns observed from the GEFPatagonia 1 and 2 cruises made at nearly identical positions during spring and late summer, as well as in other cruises. $P$. reticulatum cells appeared in shelf waters and the shelf break zone at the northern area in spring, while they were recorded in southern waters of the Patagonian shelf during autumn. Observations on a north-south direction in the progression of the spring bloom through analysis of seasonal variability of satellite-derived chlorophyll-a (Romero et al., 2006), and of paralytic shellfish toxicity maxima associated with the development and growth of $A$. tamarense (Carreto et al., 1998) were also made in this region.

Our data on viable resting cysts of Protoceratium reticulatum in surface sediments also showed a wide latitudinal distribution extending to the Uruguayan shelf and to the south of SJG, from its record offshore from the Río de la Plata (as Operculodinium centrocarpum, Wall et al., 1977) and the tidal flats of the Bahía Blanca estuary (Grill and Guerstein, 1995). In addition, living cysts were found further south $\left(\sim 49^{\circ} \mathrm{S}\right)$ together with motile cells in the planktonic environment. These cysts, of apparently recent formation, suggested that an encystment process could have been occurring when we sampled. However, cell abundance was still

\footnotetext{
2 Silvia Méndez, Dirección Nacional de Recursos Acuáticos-DINARA, Constituyente 1497, Montevideo, Uruguay.
}

relatively low, a different situation than that usually observed in dinoflagellates in which encystment occurs at high cell concentration, sometimes in bloom conditions (e.g. Garcés et al., 2004), as was quoted by Reinecke (1967) for this species. The high cyst abundance and proportion in dinoflagellate assemblages found in shelf sediments from the AUCFZ and Patagonia, shows that $P$. reticulatum is one of its most important members, as has been shown in offshore pelagic and outer neritic environments of this and other regions (e.g. Wall et al., 1977; Marret and Vernal, 1997). Protoceratium reticulatum was mentioned as relatively abundant in plankton samples from near the EPEA station and Península Valdés (Balech, 1978). The EPEA is known as an area of development of a coastal frontal system (Carreto et al., 1995), and near Península Valdés a tidal front develops during the warm period of the year (e.g. Acha et al., 2004), and in both areas benthic cyst beds and blooms of the toxic A. tamarense are known to occur (Carreto et al., 1985). The high cyst values often shown by $P$. reticulatum in benthic sediments near to these frontal zones and its occasional high abundance in planktonic populations highlights the need to pay attention to the dynamics of this species in shelf areas of potential risk of shellfish contamination.

\subsection{Toxins}

Numerous Protoceratium reticulatum strains from diverse locations have been proven to produce YTX and derivatives in culture (e.g. MacKenzie et al., 1998; Ciminiello et al., 2003; Konishi et al., 2004; Paz et al., 2004, 2007, 2013; Finch et al., 2005; Krock et al., 2008a; Röder et al., 2009). To our knowledge there are only two reports of non-toxigenic isolates of $P$. reticulatum (Rhodes et al., 2006; Paz et al., 2007), of which one (Paz et al., 2007) is contradictory to studies by Paz et al. (2004) and Röder (2010) and might be due to loss of toxicity in culture (B. Paz, pers. comm., see footnote 1 ). For this reason it must be taken into account that natural variability in YTX production - existing toxic and not toxic strains - have been observed in other gonyaulacoid species as well such as in Lingulodinium polyedrum (Reis et al., 2008) and thus may be a common trait among these species. The YTX cell quotas calculated for $P$. reticulatum from the net hauls were in the same range as the toxin cell quotas observed in the two isolates $\mathrm{A} 2$ and $\mathrm{H} 1$, and thus indicate that the factors that influence toxin production in lab conditions were similar to those in the SJG at the sampling time. The YTX cell quotas of approximately $10 \mathrm{pg}$ cell $^{-1}$ of Argentinean field samples and $P$. reticulatum isolates are in the middle range of observed $P$. reticulatum YTX cell quotas worldwide which range from 0.3 to $72 \mathrm{pg} \mathrm{cell}^{-1}$ (Paz et al., 2008). However, YTX content of field samples may also be influenced by the presence of Gonyaulax spinifera, which has also been shown to be a YTX producer in some areas. Whereas Rhodes et al. (2006) used only ELISA assays for the identification of YTX for a New Zealand isolate of $G$. spinifera and thus cannot attribute to its toxin profile, other authors report that G. spinifera YTX-profiles are dominated by homo-YTX and that yessotoxin is only a minor compound in isolates from the Adriatic Sea (Riccardi et al., 2009) and the Benguela Current (C. Chikwililwa, pers. comm. ${ }^{3}$ ). However, in none of the YTX containing samples, traces of homo-YTX could be detected. Furthermore, at station C43 no other known YTXproducers aside from $P$. reticulatum were present in the net haul sample. In addition there is no correlation between $G$. spinifera/P. reticulatum cell ratios and calculated $P$. reticulatum cell quotas. Taking all this information together, there is strong evidence that G. spinifera did not contribute to total YTX-toxicity in the SJG

\footnotetext{
${ }^{3}$ Chibo Chikwililwa, Ministry of Fisheries and Marine Resources, National Marine Information and Research Centre, Strand Street, P.O. Box 912, Swakopmund, Namibia.
} 
region. However, more research is needed to unambiguously confirm this evidence. Despite the low cell abundance of $P$. reticulatum we found, the maximum value estimated fell within the range of cell concentrations associated to varying YTX levels detected in mussels (Mallat et al., 2008; Aasen et al., 2005).

An early case of shellfish toxicity associated to this species was reported by Reinecke (1967) and Grindley and Nel (1970) in South African waters. Mouse bioassays with contaminated shellfish resulted in mouse mortalities which was suspected to be due to paralytic shellfish poisoning toxins (PSP) at that time. In contrast, mouse bioassays with plankton bloom extracts did not result in the expected mouse mortality (Grindley and Nel, 1970). Grindley and Nel used the extraction method for PSP toxins published by Sommer and Meyer (1937) which uses ethanol or methanol as extraction solvents for the toxins. However, these organic solvents would also efficiently extract lipophilic phycotoxins such as YTX from the samples. Taking into account that (1) the bloom samples were dominated by Protoceratium reticulatum, (2) YTX are less toxic than PSP toxins (which would explain why shellfish samples from bivalve mollusks, which can accumulate toxins to very high levels, were toxic, but not plankton extracts), and (3) organic extraction solvents were used, it is very likely that shellfish toxicities in fact were caused by YTX. Later the presence of $P$. reticulatum and its YTX-production in the same geographic area was unambiguously proven by tandem mass spectrometry (Krock et al., 2008a).

With respect to the other two known species that produce YTX, Lingulodinium polyedrum has been recorded in the ocean environment of the Southwest Atlantic in warm waters of the Brazil Current (Balech, 1988), but we have not found its motile cells even though their cysts were present in sediments of the EPEA station and the AUCFZ. In contrast, Gonyaulax spinifera is a species of widespread distribution in shelf waters of Argentina (Balech, 1988; Akselman, 1996) and we have recorded its cells at the SJG and also dinocysts of the G. spinifera complex as an important fraction in surface sediments. YTX were previously reported in South America from planktonic samples in north Chilean waters and in mussels from the southern coast (Yasumoto and Takizawa, 1997; Krock et al., 2009), being also detected in mussel cultures in Brazil (Schramm et al., 2010), but without knowing the causative organism. Yet in Argentina there are no information on YTX in shellfish, but our data clearly show that yessotoxins are present in plankton samples from the Patagonian area. Based on yessotoxin production and profile of local Protoceratium reticulatum isolates and on cooccurrence of YTX content and cell densities of this species in field samples we presented evidence that the main causal organism of YTX in the austral Southwest Atlantic is P. reticulatum.

\section{Conclusions}

Protoceratium reticulatum shows a large geographical distribution in the southern area of the Southwest Atlantic, with both its cells in the plankton habitat as well as its cysts in surface sediments. The high abundance of $P$. reticulatum viable cysts found in shelf sediments near to frontal zones such as those of Península Valdés in Patagonia and the area of the time-series station EPEA in northern Argentina, suggest the need to pay attention to the dynamics of this species in shelf areas of potential risk. In this study we have shown the presence of YTX in plankton samples of the SJG, and its production in culture by two $P$. reticulatum strains isolated from this locality. Although still there are no records of YTX in shellfish from this region, their occurrence raises the need for vigilance given the importance of commercial bivalve fisheries such as those for green-lipped mussels Mytilus edulis and scallops Zygochlamys patagonica. The ML analysis of sequences of the hypervariable region of the large subunit (LSU) 28S rDNA showed that the two clonal strains from the SJG were part of a monophyletic clade that subdivides into two well-supported, divergent sub-clades. The sequences of the two clonal strains fell in the same clade as the majority of sequences of $P$. reticulatum and belong to a geographically wide distributed evolutionary clade. Future investigations in $P$. reticulatum need to acknowledge the cryptic (molecular) diversity in P. reticulatum in order to assess the specific bloom ecological and toxicity characteristics of the distinct clades.

\section{Acknowledgements}

This work was partially financed by the HGF through the research program PACES of the Alfred Wegener Institute (AWI) and the binational project MINCyT-BMBF (AL/11/03-ARG 11/021). It was also supported by grants GEF-PNUD ARG 02/18, GEF-PNUD RLA/99/G31 (FREPLATA) and Consejo Nacional de Investigaciones Científicas y Técnicas (CONICET) PIP 01734 and by PIP 00173 (CONICET) grant and by the European Commission under the 7th Framework Program through the Action - IMCONet (FP7 IRSES, action no. 319718). We thank P. Sarmiento from the MEB service (Museo de La Plata), R. Reta, A.D. Cucchi Colleoni and M. Carignan (INIDEP) for technical assistance, and crews of the RVs of INIDEP and CONICET-MINDEF, Argentina, for onboard collaboration; L. Rhodes and K. Smith (Cawthron Institute, Nelson, New Zealand) are kindly acknowledged for providing LSU sequences of strains of P. reticulatum from New Zealand. This is Contribution No. 1929 of the Instituto Nacional de Investigación y Desarrollo Pesquero (INIDEP), Mar del Plata, Argentina.[SS].

\section{References}

Aasen, J., Samdal, I.A., Miles, C.O., Dahl, E., Briggs, L.R., Aune, T., 2005. Yessotoxins in Norwegian blue mussels (Mytilus edulis): uptake from Protoceratium reticulatum, metabolism and depuration. Toxicon 45, 265-272.

Acha, E.M., Mianzan, H.W., Guerrero, R.A., Favero, M., Bava, J., 2004. Marine fronts at the continental shelves of austral South America. Physical and ecological processes. J. Mar. Syst. 44, 83-105.

Akselman, R., 1996. Estudios ecológicos en el Golfo San Jorge y adyacencias (Atlántico Sudoccidental). Distribución, abundancia y variación estacional del fitoplancton en relación a factores físico-químicos y la dinámica hidrológica. (Tesis Doctoral) Facultad de Ciencias Exactas y Naturales, Universidad de Buenos Aires 234 pp.

Akselman, R., 1999. Abundancia y distribución temporal de quistes de reposo de dinoflagelados en sedimentos recientes de una estación fija en la plataforma frente a Mar del Plata, Argentina. $3^{\circ}$ Congreso Latinoamericano sobre Ciencias del Mar. Trujillo, Perú, Libro de resúmenes ampliados 1, pp. 323-324.

Alves-de-Souza, C., Varela, D., Navarrete, F., Fernández, P., Leal, P., 2008. Distribution, abundance and diversity of modern dinoflagellate cyst assemblages from southern Chile (43-54 S). Bot. Mar. 51, 399-410.

Anderson, D.M., Alpermann, T.J., Cembella, A.D., Collos, Y., Masseret, E., Montresor, M., 2012. The globally distributed genus Alexandrium: multifaceted roles in marine ecosystems and impacts on human health. Harmful Algae 12, 10-35.

Arévalo, F., Pazos, Y., Correa, J., Salgado, C., Moroño, A., Paz, B., Franco, J.M., 2004 First report of yessotoxins in mussels of Galician Rías during a bloom of Lingulodinium polyedrum Stein (Dodge). In: Henshilwood, K., Deegan, B., McMahon, T., Cusack, C., Keaveney, S., Silke, J., O’Cinneide, M., Lyons, D., Hess, P. (Eds.), 5 International Conference on Molluscan Shellfish Safety, Galway, Ireland, pp. 184-189.

Balech, E., 1971. Microplancton de la campaña oceanográfica Productividad III. Rev Mus. Arg. Cs. Nat. "B. Rivadavia”, Hidrobiol. 3, 202 pp., 39 pl.

Balech, E., 1978. Microplancton de la campaña Productividad IV. Rev. Mus. Arg. Cs. Nat. "B. Rivadavia", Hidrobiol. 5, 137-201, 9 pl.

Balech, E., 1988. Los dinoflagelados del Atlántico Sudoccidental. Publ. Espec., Inst. Español de Oceanogr. 1, 310 pp.

Belin, C., Zouher, A., 2009. Phycotoxin monitoring in France: risk-based strategy and main results. In: 7th International Conference on Molluscan Shellfish Safety, Conference Handbook, Nantes, France, p. 40.

Bianchi, C., Fato, R., Angelin, A., Trombetti, F., Ventrella, V., Borgatti, A.R., Fattorusso, E., Ciminiello, P., Bernardi, P., Lenaz, G., Parenti, C.G., 2004. Yessotoxin, a shellfish biotoxin, is a potent inducer of the permeability transition in isolated mitochondria and intact cells. Biochim. Biophys. Acta 1656, 139-147.

Bolch, C.J.S., de Salas, M.F., 2007. A review of the molecular evidence for ballast water introduction of the toxic dinoflagellates Gymnodinium catenatum and the Alexandrium tamarensis complex to Australasia. Harmful Algae 6, 465-485.

Borel, C.M., Cervellini, P.M., Guerstein, G.R., 2006. Quistes de dinoflagelados de sedimentos Holocenos y dinoflagelados modernos del estuario de Bahía Blanca, Argentina. Geoacta 31, 23-31. 
Borromei, A.M., Quattrocchio, M.E., 2001. Palynological study of Holocene marine sediments from Bahía Lapataia, Beagle Channel, Tierra del Fuego, Argentina. Rev. Esp. Micropaleontol. 33, 61-70.

Braarud, T., 1945. Morphological observations on marine dinoflagellate cultures Norske Videnskaps-Akad. Oslo 1. Mat.-Naturv. Kl. 11, 1-18, 4 pl.

Bütschli, O., 1885. Dinoflagellata, in Protozoa (1880-89) in Bronn. Klass u. Ordn. des Tierreichs 1, 906-1029, pl. 51-55.

Cardoso, L.S., 1998. Dinoflagelados da Ilha do Arvoredo e da Praia de Ponta das Canas, Santa Catarina, Brasil. Biociênc. P. Alegre 6, 3-54

Carreto, J.I., Negri, R.M., Benavides, H.R., Akselman, R., 1985. Toxic dinoflagellate blooms in the Argentine sea. In: Anderson, D.M., White, A.W., Baden, D.G. (Eds.) Toxic Dinoflagellates. Elsevier, NY, pp. 147-152.

Carreto, J.I., Lutz, V.A., Carignan, M.O., Cucchi Colleoni, A.D., De Marco, S.G., 1995 Hydrography and chlorophyll-a in a transect from the coast to the shelf-break in the Argentine sea. Cont. Shelf Res. 15, 315-336.

Carreto, J.I., Montoya, N.G., Cucchi Colleoni, A.D., Akselman, R., 1998. Alexandrium tamarense blooms and shellfish toxicity in the Argentine Sea: a retrospective view. In: Reguera, B., Blanco, J., Fernández, M.L., Wyatt, T. (Eds.), Harmful Microalgae. IOC-UNESCO, pp. 131-134.

Ciminiello, P., Fattorusso, E., Forino, M., Magno, S., Poletti, R., Satake, M., Viviani, R. Yasumoto, T., 1997. Yessotoxin in mussels of the northern Adriatic Sea. Toxicon 35, 177-183.

Ciminiello, P., Dell-Aversano, C., Fattorusso, E., Forino, M., Magno, S., Guerrini, F. Pistocchi, R., Boni, L., 2003. Complex yessotoxins profile in Protoceratium reticulatum from north-western Adriatic sea revealed by LC-MS analysis. Toxicon 42, 7-14.

Claparède, E., Lachmann, J., 1858-1859. Etude sur les infusoires et les rhizopodes. Mém. Inst. Genevois 5-6, 489 pp., 13 pl.

Daugbjerg, N., Hansen, G., Larsen, J., Moestrup, O., 2000. Phylogeny of some of the major genera of dinoflagellates based on ultrastructure and partial LSU rDNA sequence data, including the erection of three new genera of unarmoured dinoflagellates. Phycologia 39, 302-317.

Deflandre, G., Cookson, I.C., 1955. Fossil microplankton from Australian Late Mesozoic and Tertiary sediments. Aust. J. Mar. Freshw. Res. 6, 242-314.

Draisci, R., Ferretti, E., Palleschi, L., Marchiafava, C., Poletti, R., Milandri, A., Ceredi, A., Pompei, M., 1999. High levels of yessotoxin on mussels and presence of yessotoxin and homo-yessotoxin in dinoflagellates of the Adriatic Sea. Toxicon 37, 1187-1193.

Ellegaard, M., Daugbjerg, N., Rochon, A., Lewis, J., Harding, I., 2003. Morphological and LSU rDNA sequence variation within the Gonyaulax spinifera-Spiniferites group (Dinophyceae) and proposal of G. elongata comb. nov. and G. membranacea comb. nov. Phycologia 42, 151-164.

Ferrario, M.E., Sar, E.A., Salas, S., 1995. Metodología básica para el estudio del fitoplancton con espacial referencia a las diatomeas. In: Alveal, K., Ferrario, M.E. Oliveira, E.C., Sar, E.A. (Eds.), Manual de Métodos Ficológicos. Universidad de Concepción, Edit. A. Pinto, Concepción, pp. 1-23

Finch, S.C., Wilkins, A.L., Hawkes, A.D., Jensen, D.J., MacKenzie, L., Beuzenberg, V. Quilliam, M.A., Olseng, C.D., Samdal, I.A., Aasen, J.A., Selwood, A.I., Cooney, J.M., Sandvik, M., Miles, C.O., 2005. Isolation and identification of (44-R,S)-44,55dihydroxyyessotoxin from Protoceratium reticulatum and its occurrence in extracts of shellfish from New Zealand, Norway and Canada. Toxicon 46 $160-170$.

Fritz, L., Triemer, R.F., 1985. A rapid simple technique utilizing Calcofluor White M2R for the visualization of dinoflagellate thecal plates. J. Phycol. 21, 662-664.

Garcés, E., Bravo, I., Vila, M., Figueroa, R.I., Masó, M., Sampedro, N., 2004. Relationships between vegetative cells and cyst production during Alexandrium minutum bloom in Arenys de Mar harbour (NW Mediterranean). J. Plankton Res. 26, 637-645.

Grill, S.C., Guerstein, G.R., 1995. Estudio palinológico de sedimentos superficiales en el estuario de Bahía Blanca, Buenos Aires (Argentina). Polen 7, 40-49.

Grindley, J.R., Nel, E.A., 1970. Red water and mussel poisoning at Elands Bay, December 1966. Fish. Bull. S. Afr. 6, 36-55.

Guerrero, R.A., Piola, A.R., 1997. Masas de agua en la plataforma continental. In: Boschi, E.E. (Ed.), El Mar Argentino y sus recursos pesqueros. Tomo 1. Antecedentes históricos de las exploraciones en el mar y las características ambientales. Publicaciones Especiales INIDEP, Mar del Plata, pp. 107-118.

Guindon, S., Gascuel, O., 2003. A simple, fast, and accurate algorithm to estimate large phylogenies by maximum likelihood. Syst. Biol. 52, 696-704.

Guiry, M.D., Guiry, G.M., 2014. AlgaeBase. World-wide Electronic Publication, National University of Ireland, Galway. http://www.algaebase.org (accessed 21.07.14).

Hällfors, G., 2004. Checklist of Baltic Sea phytoplankton species (including some heterotrophic protistan groups). Baltic Sea Environ. Proc. 95, 208 pp.

Hansen, G., Moestrup, O., Roberts, K.R., 1996/1997. Light and electron microscopical observations on Protoceratium reticulatum (Dinophyceae). Arch. Protistenk. 147, 381-391.

Harland, R., 1983. Distribution maps of recent dinoflagellate cysts in bottom sediments from the North Atlantic Ocean and adjacent seas. Palaeontology 26, 321-387.

Hasle, G.R., 1978. The inverted-microscope method. In: Sournia, A. (Ed.), Phytoplankton Manual. UNESCO, Monogr. Oceanogr. Methodol. 6, pp. 88-96.

Hernández-Becerril, D.U., 1988. Planktonic dinoflagellates (except Ceratium and Protoperidinium) from the Gulf of California and off the coasts of Baja California. Bot. Mar. 31, 423-435.

Herrera-Sepúlveda, A., Hernández-Saavedra, N.Y., Medlin, L.K., West, N., 2013 Capillary electrophoresis finger print technique (CE-SSCP): an alternative too for the monitoring activities of HAB species in Baja California Sur Costal. Environ. Sci. Pollut. Res. 20, 6863-6871.

Higman, W.A., Stone, D.M., Lewis, J.M., 2001. Sequence comparisons of toxic and non-toxic Alexandrium tamarense (Dinophyceae) isolates from UK waters. Phycologia 40, 256-262.

Howard, M.D.A., Silver, M., Kudela, R.M., 2008. Yessotoxin detected in mussel (Mytilus californicus) and phytoplankton samples from the U.S. west coast. Harmful Algae 7, 646-652.

Howard, M.D.A., Smith, G.J., Kudela, R.M., 2009. Phylogenetic relationships of yessotoxin-producing dinoflagellates, based on the large subunit and internal transcribed spacer ribosomal DNA domains. Appl. Environ. Microbiol. 75, 54-63.

John, U., Fensome, R.A., Medlin, L.K., 2003. The application of a molecular clock based on molecular sequences and the fossil record to explain biogeographic distributions within the Alexandrium tamarense species complex (Dinophyceae). Mol. Biol. Evol. 20, 1015-1027.

Keller, M.D., Selvin, R.C., Claus, W., Guillard, R.R.L., 1987. Media for the culture of oceanic ultraphytoplankton. J. Phycol. 23, 633-638.

Kim, K.Y., Garbary, D.J., McLachlan, J.L., 2004. Phytoplankton dynamics in Pomquet Harbour, Nova Scotia: a lagoon in the southern Gulf of St. Lawrence. Phycologia 43, 311-328.

Kim, K.-Y., Hwang, C.-H., Lee, C.-K., Kim, C.-H., 2006. Phylogenetic analysis of dinoflagellate Gonyaulax polygramma Stein responsible for harmful algal blooms based on the partial LSU rDNA sequence data. Algae 21, $283-$ 286

Kim, K.-Y., Kim, C.-H., 2007. Phylogenetic relationships among diverse dinoflagellate species occurring in coastal waters off Korea inferred from large subunit ribosomal DNA sequence data. Algae 22, 57-67.

Konishi, M., Yang, X., Li, B., Fairchild, C.R., Shimizu, Y., 2004. Highly cytotoxic metabolites from the culture supernatant of the temperate dinoflagellate Protoceratium cf reticulatum. J. Nat. Prod. 67, 1309-1313.

Krock, B., Alpermann, T., Tillmann, U., Pitcher, G.C., Cembella, A.D., 2008a. Yessotoxin profiles of the marine dinoflagellates Protoceratium reticulatum and Gonyaulax spinifera. In: Moestrup, Ø. et al. (Eds.), Proceedings 12th International Conference on Harmful Algae, ISSHA and IOC-UNESCO, Copenhagen, Denmark, pp. 303-305.

Krock, B., Tillmann, U., John, U., Cembella, A.D., 2008b. LC-MS-MS aboard ship: tandem mass spectrometry in the search for phycotoxins and novel toxigenic plankton from the North Sea. Anal. Bioanal. Chem. 392, 797-803.

Krock, B., Seguel, C.G., Valderrama, K., Tillmann, U., 2009. Pectenotoxins and yessotoxin from Arica Bay, North Chile as determined by tandem mass spectrometry. Toxicon 54, 364-367.

Lilly, E.L., Halanych, K.M., Anderson, D.M., 2007. Species boundaries and global biogeography of the Alexandrium tamarense complex (Dinophyceae). J. Phycol. 43, 1329-1338.

MacKenzie, L., Truman, P., Satake, M., Yasumoto, T., Adamson, J., Mountfort, D., White, D., 1998. Dinoflagellate blooms and associated DSP-toxicity in shellfish in New Zealand. In: Reguera, B., Blanco, J., Fernández, M.L., Wyatt, T. (Eds.), Harmful Microalgae. IOC-UNESCO, pp. 74-77.

Mallat, E., Cañete, E., Caillaud, A., Fernández, M., Bravo, I., Paz, B., Franco, J.M., Diógene, J., 2008. Evidence of yessotoxins in Alfacs Bay - toxic effect evaluation by cell-based assays and toxin profile determination by liquid chromatography. In: Moestrup, Ø. et al. (Eds.), Proceedings of the 12th International Conference on Harmful Algae, ISSHA and IOC-UNESCO, Copenhagen, Denmark, pp. 374-376.

Marret, F., Vernal, A., 1997. Dinoflagellate cyst distribution in surface sediments of the southern Indian Ocean. Mar. Micropaleontol. 29, 367-392.

Marret, F., Zonneveld, K.A.F., 2003. Atlas of modern organic-walled dinoflagellate cyst distribution. Rev. Palaeobot. Palynol. 125, 1-200.

Matsuoka, K., 1985. Organic-walled dinoflagellate cysts from surface sediments of Nagasaki Bay and Senzaki Bay, West Japan. Bull. Fac. Liberal Arts, Nagasaki Univ. 25 (2), 21-115.

Mertens, K.N., Bringue, M., Van Nieuwenhove, N., Takano, Y., Pospelova, V., Rochon, A., De Vernal, A., Radi, T., Dale, B., Patterson, R.T., Weckstrom, K., Andren, E., Louwye, S., Matsuoka, K., 2012. Process length variation of the cyst of the dinoflagellate Protoceratium reticulatum in the North Pacific and Baltic-Skagerrak region: calibration as an annual density proxy and first evidence of pseudocryptic speciation. J. Quat. Sci. 27, 734-744.

Miles, C.O., Samdal, I.A., Aasen, J.A.G., Jensen, D.J., Quilliam, M.A., Petersen, D., Briggs, L.M., Wilkins, A.L., Rise, F., Cooney, J.M., MacKenzie, L.A., 2005. Evidence for numerous analogs of yessotoxin in Protoceratium reticulatum. Harmful Algae 4, 1075-1091.

Morton, S.L., Vershinin, A., Leighfield, T., Smith, L., Quilliam, M., 2007. Identification of yessotoxin in mussels from the Caucasian Black Sea Coast of the Russian Federation. Toxicon 50, 581-584.

Murata, M., Kumagai, M., Lee, J.S., Yasumoto, T., 1987. Isolation and structure of yessotoxin, a novel polyether compound implicated in diarrhetic shellfish poisoning. Tetrahedron Lett. 28, 5869-5872

Odebrecht, C., 2010. Dinophyceae. In: Forzza et al. (Eds.), Catálogo de plantas e fungos do Brasil, vol. 1, pp. 366-383.

Orlova, T.Y., Morozova, T.V., Gribble, K.E., Kulis, D.M., Anderson, D.M., 2004. Dinoflagellate cysts in recent marine sediments from the east coast of Russia. Bot. Mar. 47, 184-201.

Orr, R.J.S., Stuken, A., Rundberget, T., Eikrem, W., Jakobsen, K.S., 2011. Improved phylogenetic resolution of toxic and non-toxic Alexandrium strains using a concatenated rDNA approach. Harmful Algae 10, 676-688. 
Paz, B., Riobó, P., Fernández, M.L., Fraga, S., Franco, J.M., 2004. Production and release of yessotoxins by the dinoflagellates Protoceratium reticulatum and Lingulodinium polyedrum in culture. Toxicon 44, 251-258.

Paz, B., Riobó, P., Ramilo, I., Franco, J.M., 2007. Yessotoxins profile in strains of Protoceratium reticulatum from Spain and USA. Toxicon 50, 1-17.

Paz, B., Daranas, A.H., Norte, M., Riobó, P., Franco, J.M., Fernández,J.J., 2008. Yessotoxins, a group of marine polyether toxins: an overview. Mar. Drugs 6 (2), 73-102.

Paz, B., Blanco, J., Franco, J.M., 2013. Yessotoxins production during the culture of Protoceratium reticulatum strains isolated from Galician Rias Baixas (NW Spain). Harmful Algae 21-22, 13-19.

Posada, D., 2008. jModelTest: phylogenetic model averaging. Mol. Biol. Evol. 25, $1253-1256$

Quilliam, M.A., Garnett, C.M., Lewis, N.I., Yu, R., Hardstaff, W., van de Riet, J.M., Potter, R.A., Rourke, W.A., Burns, B.G., 2006. Emerging algal toxins in Canada. In: 12th Intern. Conf. on Harmful Algae, Abstracts, Copenhagen, Denmark, p. 266.

Reid, P.C., 1978. Dinoflagellate cysts in the plankton. New Phytol. 80, 219-229.

Reinecke, P., 1967. Gonyaulax grindleyi sp. nov.: a dinoflagellate causing a red tide at Elands Bay, Cape Province, in December 1966. J. S. Afr. Bot. 33, 157-160.

Reis, M., Kraberg, A.C., Amorim, A., Erler, K., Luckas, B., Wiltshire, K.H., 2008. An investigation into the ecotoxicology of different strains of Lingulodinium polyedrum from the Portuguese coast. In: Moestrup, Ø. et al. (Eds.), Proceedings of the 12th International Conference on Harmful Algae, ISSHA and IOC-UNESCO, Copenhagen, Denmark, pp. 323-325.

Rhodes, L., McNabb, P., de Salas, M., Briggs, L., Beuzenberg, V., Gladstone, M., 2006. Yessotoxin production by Gonyaulax spinifera. Harmful Algae 5, 148-155.

Riccardi, M., Guerrini, F., Pistocchi, R., Tinti, F., Boni, L., 2006. Molecular characterization of different strains of Protoceratium reticulatum (Claparede \& Lachmann) Buetschli. Biol. Mar. Mediterr. 13, 1042-1044.

Riccardi, M., Guerrini, F., Roncarati, F., Milandri, A., Cangini, M., Pigozzi, S., Riccardi, E., Ceredi, A., Ciminiello, P., Dell'Aversano, C., Fattorusso, E., Forino, M., Tartaglione, L., Pistocchi, R., 2009. Gonyaulax spinifera from the Adriatic sea: toxin production and phylogenetic analysis. Harmful Algae 8, 279-290.

Röder, K., Dressler, N., Gerdts, G., Luckas, B., 2009. Accumulation and metabolism of yessotoxin produced by Protoceratium reticulatum in blue mussel (Mytilus edulis) and pacific oyster (Crassostrea gigas). In: 7th International Conference on Molluscan Shellfish Safety, Conference Handbook, Nantes, France, p. 190.

Röder, K., 2010. Analytik und Vorkommen lebensmittelrechtlich relevanter mariner Biotoxine unter besonderer Berücksichtigung von Ciguatoxinen (CTXs) und Yessotoxinen (YTXs). Dissertation Dr. rer. nat.Biologisch-Pharmazeutische Fakultät, Friedrich-Schiller-Universität Jena 168 pp.

Romero, S.I., Piola, A.R., Charo, M., Eiras García, C.A., 2006. Chlorophyll-a variability off Patagonia based on SeaWIFS data. J. Geophys. Res. 3, C05021, http:// dx.doi.org/10.1029/2005JC003244.

Ruiz Sebastián, C., O’Ryan, C., 2001. Single-cell sequencing of dinoflagellate (Dinophyceae) nuclear ribosomal genes. Mol. Ecol. Notes 1, 329-331.

Satake, M., MacKenzie, L., Yasumoto, T., 1997. Identification of Protoceratium reticulatum as the biogenic origin of yessotoxin. Nat. Toxicol. 5, 164-167.

Scholin, C., Herzog, A.M., Sogin, M., Anderson, D.M., 1994. Identification of group- and strain-specific genetic markers for globally distributed Alexandrium (Dinophyceae). II. Sequence analysis of a fragment of the LSU rDNA gene. J. Phycol. 30, 999-1011.

Schramm, M.A., Alves, T.P., Honorato, M.C. Proença, L.A.O., 2010. Primeira detecção de ficotoxinas lipofílicas em mexilhões da Armação do Itapocorói em Santa Catarina através de LC-MS/MS. In: XIII Congresso Brasileiro de Ficologia, Paraty, RJ, Resumos.
Scorzetti, G., Brand, L.E., Hitchcock, G.L., Rein, K.S., Sinigalliano, C.D., Fell, J.W., 2009 Multiple simultaneous detection of harmful algal blooms (HABs) through a high throughput bead array technology, with potential use in phytoplankton community analysis. Harmful Algae 8, 196-211.

Seguel, M., Tocornal, M.A., Sfeir, A., 2005. Floraciones algales nocivas en los canales y fiordos del sur de Chile. Cienc. Tecnol. Mar. 28, 5-13.

Sommer, H., Meyer, K.F., 1937. Paralytic shellfish poisoning. Arch. Pathol. 24, 560598.

Steidinger, K.A., Williams, J., 1970. Dinoflagellates. Memoirs of the Hourglass Cruises 2. Mar. Res. Lab., Florida Dep. Nat. Res., St. Petersburg, Florida, USA $251 \mathrm{pp}$.

Steidinger, K.A., Tangen, K., 1996. Dinoflagellates. In: Tomas, C.R. (Ed.), Identifying Marine Diatoms and Dinoflagellates. Academic Press, Inc., pp. 387-598.

Stockmarr, J., 1971. Tablets with spores used in absolute pollen analysis. Pollen Spores 13, 615-621.

Taylor, F.J.R., Fukuyo, Y., Larsen, J., Hallegraeff, G.M., 2004. Taxonomy of harmful dinoflagellates. In: Hallegraeff, G.M., Anderson, D.M., Cembella, A.D. (Eds.), Manual on Harmful Marine Microalgae. Monographs on Oceanographic Methodology, UNESCO Publ 11, pp. 389-432.

Töbe, K., Alpermann, T.J., Tillmann, U., Krock, B., Cembella, A.D., John, U., 2013. Molecular discrimination of toxic and non-toxic Alexandrium species (Dinophyta) in natural phytoplankton assemblages from the Scottish coast of the North Sea. Eur. J. Phycol. 48, 12-26.

Tubaro, A., Sidari, L., Della Loggia, R., Yasumoto, T., 1998. Occurrence of yessotoxinlike toxins in phytoplankton and mussels from northern Adriatic Sea. In: Reguera, B., Blanco, J., Fernández, M.L., Wyatt, T. (Eds.), Harmful Algae. Proceedings 8th Conf. Harmful Algae, IOC-UNESCO and X. Galicia, pp. 470-472.

Verleye, T.J., Mertens, K.N., Young, M.D., Dale, B., McMinn, A., Scott, L.F., Zonneveld K.A.F., Louwye, S., 2012. Average process length variation of the marine dinoflagellate cyst Operculodinium centrocarpum in the tropical and Southern Hemisphere Oceans: assessing its potential as a palaeosalinity proxy. Mar. Micropaleontol. 86-87, 45-58.

Vilanova, I., Guerstein, G.R., Akselman, R., Prieto, A.R., 2008. Holocene dinocysts from the Argentine inner shelf $\left(36^{\circ} \mathrm{S}\right)$ : their relationship to modern forms and their palaeoecological characterization. Rev. Palaeobot. Palinol. 152, 11-20.

Wall, D., 1967. Fossil microplankton in deep-sea cores from the Caribbean Sea. Palaeontology 10, 95-123.

Wall, D., Dale, B., 1968. Modern dinoflagellate cysts and evolution of the Peridiniales. Micropaleontology 14, 265-304, 4 pl.

Wall, D., Dale, B., Lohmann, G.P., Smith, W.K., 1977. The environmental and climatic distribution of dinoflagellate cysts in modern marine sediments from regions in the North and South Atlantic oceans and adjacent seas. Mar. Micropaleontol. 2, 121-200.

Walsh, D., Reeves, R.A., Saul, D.J., Gray, R.D., MacKenzie, L., Bergquist, P.R., Bergquist P.L., 1998. Heterogeneity of SSU and LSU rDNA sequences of Alexandrium species. Biochem. Syst. Ecol. 26, 495-509.

Wang, L., Zhuang, Y., Zhang, H., Lin, X., Lin, S., 2014. DNA barcoding species in Alexandrium tamarense complex using ITS and proposing designation of five species. Harmful Algae 31, 100-113.

Wołoszyńska, H.J., 1928. Dinoflagellatae der polnischen Ostsee sowie der Piasnica gelegenen Sümpfe. Archwm. Hydrobiol. Ryb. 3, 155-278.

Yasumoto, T., Takizawa, A., 1997. Fluorometric measurement of yessotoxins in shellfish by high-pressure liquid chromatography. Biosci. Biotechnol. Biochem. 61, 1775-1777. 